\title{
Coyo 3: Momentos finales del Período Medio en San Pedro de Atacama
}

M. Antonietta $\operatorname{Costa~}^{1}$ Y Agustín Llagostera $^{1}$

\section{RESUMEN}

Se analiza el cementerio arqueológico Coyo Occidente 3 de San Pedro de Atacama, el que por fechación radiocarbónica (promedio 930 DC) y por las evidencias culturales, corresponde a los momentos finales del Período Agroalfarero Medio. En el análisis de este sitio se ha integrado la información entregada por indicadores bioantropológicos con la de los indicadores culturales para inferir implicaciones en cuanto a estilo y calidad de vida, distribución de la población (edad y sexo), disposición de los enterratorios y de las ofrendas, caracterización artefactual y contextual, etc., para trazar en última instancia el perfil biosociocultural de una población epigonal del período referido en el Salar de Atacama. Los contextos alfareros permitieron segregar dos grupos de enterratorios, separados espacialmente por contemporáneos, lo que hace a los autores postular la existencia de "mitades", las que estarían expresando una organización sociopolítica de tipo dual.

\section{Introducción}

El Período Medio, mayormente identificado con el fenómeno Tiwanaku, suscita el gran interés de los arqueólogos por el significado que éste ha tenido en el desarrollo sociocultural de los Andes Meridionales. Como señala Rivera (1985a, 1985b), este es el momento clave en el desarrollo cuando, por circunstancias que desconocemos, logran plasmarse los principales valores de la sociedad andina. En este sentido, agrega el autor, encontramos obras de gran significado simbólico para la comunidad integrante del sistema, de alto prestigio que revelan formas de cultos, respeto a un orden configurado y desarrollado, articulación de espacios en un marco común, redistribución económica y una organización política que necesita de una centralización que controla, pero cuya responsabilidad aparece como efectivamente compartida.

Bastante se ha escrito en general y sobre sitios en particular para resaltar el auge de este período,

\footnotetext{
Instituto de Investigaciones Arqueológicas y Museo, Universidad Católica del Norte, San Pedro de Atacama, CHILE.
}

pero muy pocas referencias encontramos sobre sus postrimerías, a pesar de la capital importancia que tiene este punto para entender el declinio de esa cultura y, a través de ello, entender el fenómeno en sí, así como para comprender las circunstancias que dieron paso a los Desarrollos Regionales.

Para la zona de Arica se postuló la Fase Maytas como la más representativa del Período Medio (700-1000 DC), con toda la complejidad que le confieren las manifestaciones Chiribaya, Charcollo, Taltape y Loreto Viejo, siendo esta fase, en última instancia, la que contacta con el Período Intermedio Tardío. Para la zona de San Pedro de Atacama, la Fase Coyo (referida a Coyo Oriente) englobaría la última parte del Período Medio desde 510 a 940 DC (Berenguer et al. 1986); sin embargo, la mayor representatividad del sitio-tipo corresponde al momento álgido del influjo Tiwanaku y no es representativo del final de ella.

El cementerio de Coyo Occidente 3 (Figura 1), que en parte viene a llenar el desconocimiento aludido, se encuentra en el borde oeste del actual ayllu homónimo, emplazado en una ligera pendiente de dunas arenosas que se enfrentan a los relieves de la Cordillera de la Sal. A los pies de dichas dunas existe un antiguo cauce con vegetación relictual, consistente en un bosquecillo de chañar (Geoffroea decorticans) y pequeños arbustos autóctonos, mayormente cachichuyo (Atriplex atacamensis) y brea (Tessaria absinthoides), los que son testimonio de un antiguo lecho del río San Pedro, ahora seco.

El cementerio es bastante extenso: en él se trabajó un pequeño sector en un total de $96 \mathrm{~m}^{2}$, descubriéndose 51 tumbas.

La mala preservación de la materia orgánica resultó en un obstáculo bastante importante para la obtención de elementos posibles de ser fechados; sin embargo, hemos logrado la cantidad necesaria de restos muy destruidos de textiles de tres tumbas, con los siguientes resultados: 


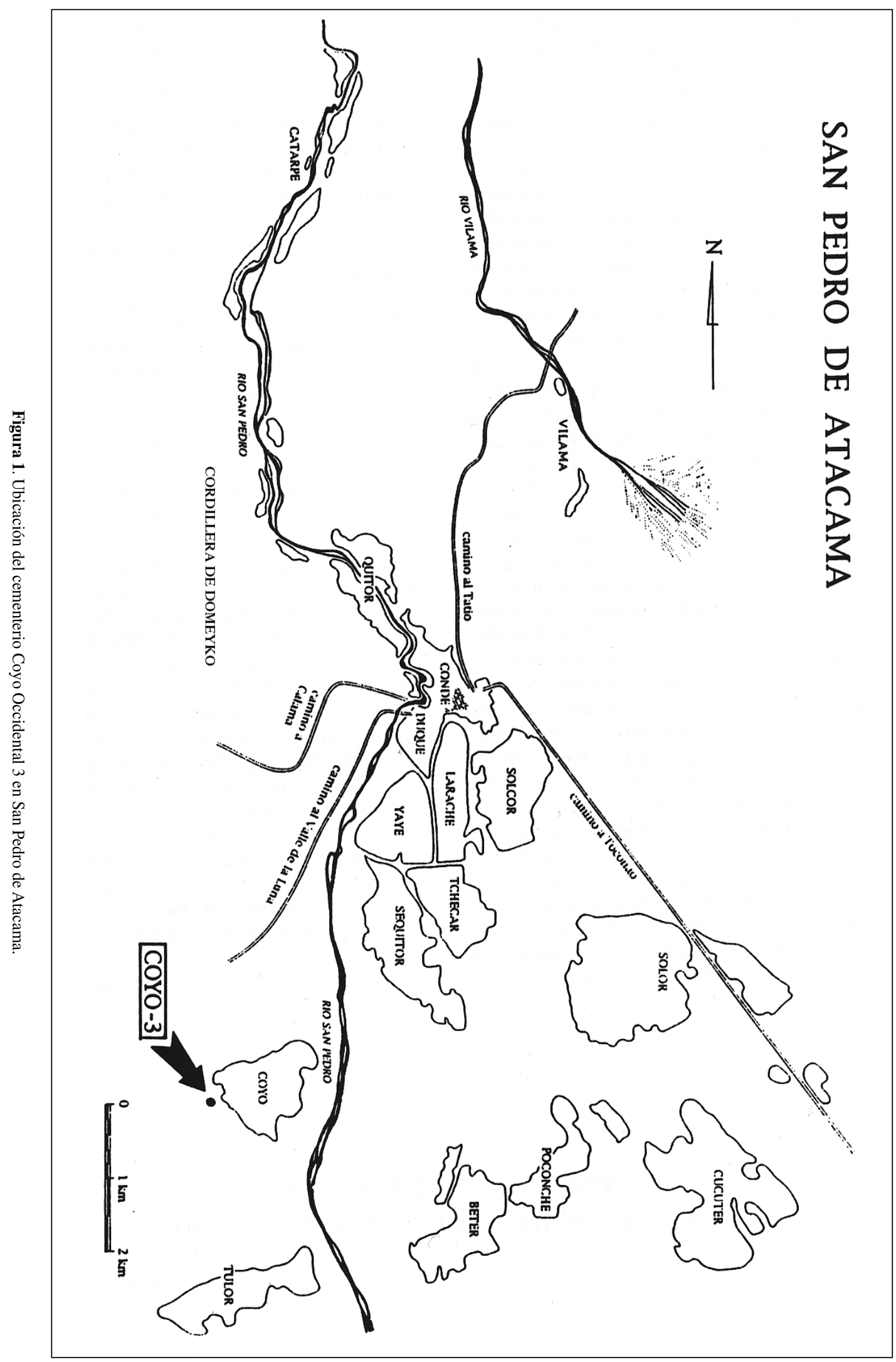


Tumba 5: $990 \pm 50$ AP: 960 DC (Beta 44674)

Tumba 15: 1040 \pm 70 AP: 910 DC (Beta 44675)

Tumba 17: 1030 \pm 80 AP: 920 DC (Beta 44673)

En el análisis de este sitio se ha integrado el uso de indicadores bioantropológicos y culturales para inferir implicaciones referentes a: estilo y calidad de vida, distribución de la población en cuanto a edad y sexo, disposición de los enterratorios y de las ofrendas, caracterización artefactual y contextual, entre otros, para, en última instancia, llegar a trazar el perfil biosociocultural de una población epigonal del Período Medio de San Pedro de Atacama.

\section{Características y composición del cementerio}

Las tumbas de Coyo 3 se caracterizaban por fosas excavadas directamente en el terreno arenoso, con una forma cilíndrica y profundidades variadas, sin ningún tipo de revestimiento o cobertura. El sector excavado del cementerio era ocupado por individuos de ambos sexos y de todas las edades. Algunas de las tumbas fueron reocupadas, a pesar de que había amplio espacio disponible entre ellas, siendo variada la composición de sus ocupantes, tanto por sexo como por edad, lo que hace pensar que algunas familias preferían enterrar a sus muertos en una misma unidad funeraria, aunque para ello fue necesario desplazar el cuerpo más antiguo. En cuanto a la distribución de tumbas, parece ocurrir una tendencia a agruparse aquéllas ocupadas por mujeres y niños, sin que ello determine una verdadera sectorización del cementerio.

La composición de los enterratorios, en cuanto a número de cuerpos enterrados, era preferentemente individual $(\mathrm{n}=37 ; 72.5 \%)$. Las tumbas dobles eran nueve (17.6\%); las triples, 2 (3.9\%); una con cuatro, otra con seis otra con nueve cuerpos $(2.0 \%)$. Esta última tumba (13) contenía un osario en el que se entremezclaban los restos de los individuos. Entre los ocupantes de las tumbas individuales había una mujer con feto in situ. La reocupación de enterratorios mencionada anteriormente significa un factor negativo en relación a la preservación del material arqueológico ya que los contextos eran revueltos y destruidos en algunos casos en el momento de reocupar la tumba. Otro factor de deterioro son las condiciones de terreno, por su composición arenosa y por la presencia de arbustos en superficie, cuyas raíces se infiltraban en el contexto.
Los cuerpos eran colocados en posición sentada preferentemente orientados mirando hacia el este. La mujer que ocupaba la tumba 23 era la única que escapaba a dicho patrón, en el sentido de que fue acomodada en decúbito lateral izquierdo; es interesante acotar que su ajuar comprendía una cerámica evidentemente foránea.

La ubicación de las tumbas no muestra una clara distribución espacial diferenciada, aunque hay dos hechos que deben destacarse a este respecto. Por un lado, si tiramos una diagonal noroeste-sureste en el área excavada vemos que en la mitad noreste quedan solamente tumbas con cerámica, mientras que en la mitad suroeste aparecen ambos tipos de tumbas entremezcladas. Por otro lado, en el sector suroeste las tumbas sin cerámica aparecen en pequeños grupos de tres o cuatro, mientras que las con cerámica muestran una distribución más dispersa. Además, se observa una tendencia a que mujeres y niños se ubiquen próximo unos a otros, concentrándose en el área suroeste, mientras que las tumbas masculinas, aunque más dispersas, tienden a concentrarse en el área noreste.

Las profundidades varían desde 20 hasta $195 \mathrm{~cm}$ aumentando hacia el oeste del cementerio; las tumbas más pequeñas corresponden, en general, a niños de corta edad y aquéllas de mayor diámetro, a los enterratorios reocupados. El ajuar de los hombres es, en general, más generoso que el de las mujeres.

\section{Material cultural}

Por los problemas de preservación en el sitio, a los cuales hemos hecho referencia, el material orgánico está pobremente representado, siendo dramático el caso de los textiles y de la cestería, de los cuales apenas se podía advertir la impronta del objeto en el terreno. La madera, cuando fue recuperada, se encontraba extremamente fragmentada y deleznable, por lo que tenemos que regirnos por las referencias de terreno, en las que anotamos la cantidad y las categorías de objetos que componían los contextos.

Aun tomando en cuenta lo anterior, se advierte que las ofrendas no son muy numerosas, aunque sí, variadas. De las 41 categorías de objetos presentes en los enterratorios, la cerámica fue el más constante, con un total de 48 piezas. 


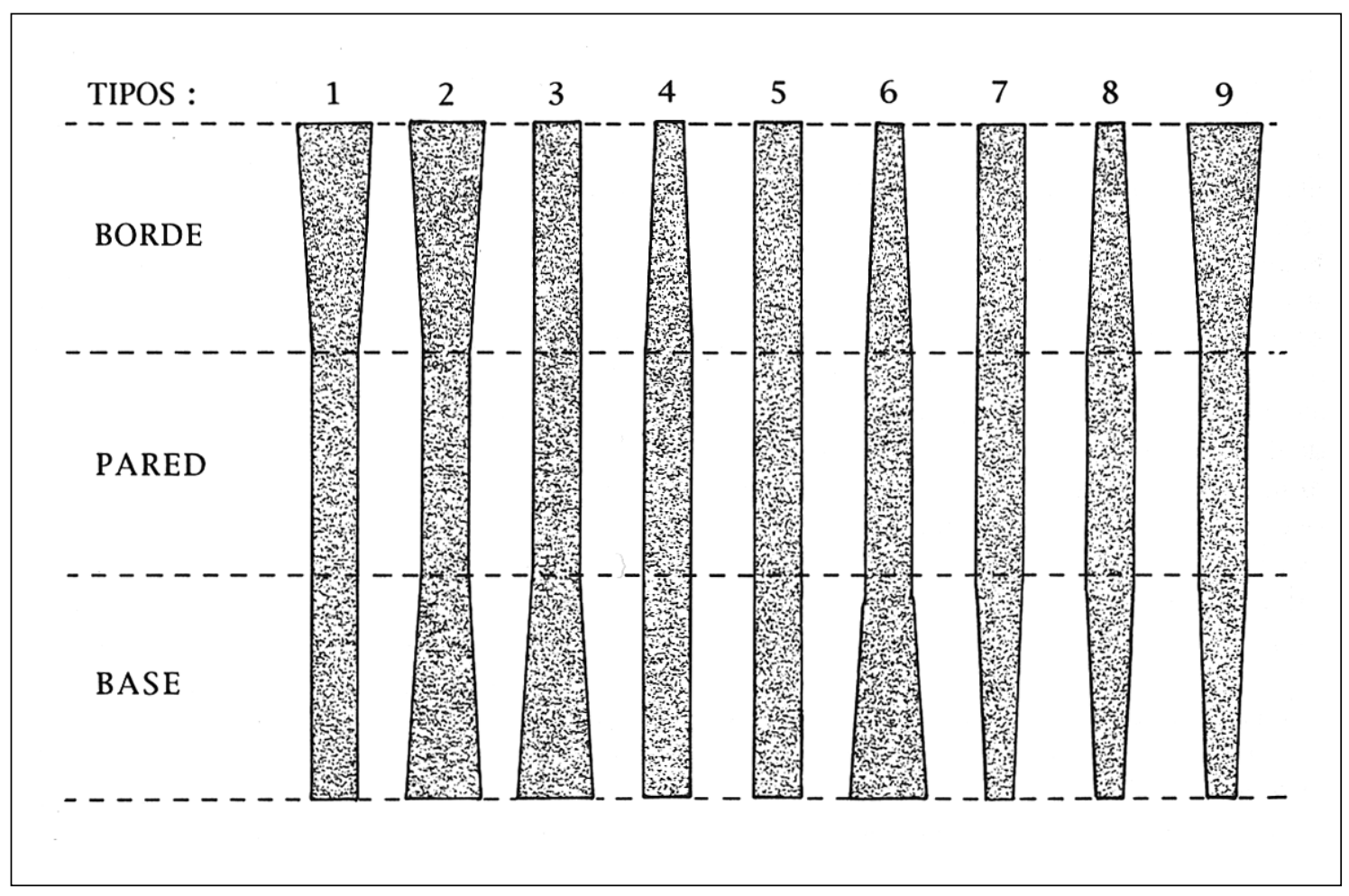

Figura 2. Tipología de los perfiles parietales de la cerámica de Coyo 3.

\section{Cerámica}

Del total de 50 tumbas consideradas, 29 presentaron ajuares con alfarería, lo que equivale a un $58 \%$ del total de tumbas del cementerio, con una media de 1.6 cerámicas por tumba. ${ }^{2}$

Para determinar las características de la cerámica se consideraron los siguientes atributos: morfológicos generales (forma general) y morfológicos específicos (formas de labio, asas, base, etc.), color, medidas longitudinales y medidas volumétricas, decoración e índices (relación entre alto y ancho, entre ancho máximo de la pieza y ancho de boca, entre volumen y espesor de pared y ubicación del ancho máximo en relación a la altura de la vasija).

Otro de los atributos considerados es lo que hemos llamado perfil parietal, en el que se integran, a nivel relativo, los espesores del borde, de la pared y de la base. Según las posibilidades de combinaciones de las tres partes que forman el perfil de la pared de la vasija, hemos definido las situaciones o tipos

2 Los materiales del osario (tumba 13) no fueron considerados en el análisis del material cultural. específicos que se muestran en la Figura 2. Por su parte, para la forma de los labios se establecieron siete tipos (Figura 3).

De acuerdo a la distribución y proximidad de los valores de los atributos en las piezas alfareras se definieron 17 tipos, los que se describen detalladamente en Anexo (Figuras 4, 5 y 6). ${ }^{3}$

Al contrastar el conjunto de individuos enterrados con cerámica y al grupo que carece de ella, vemos que el primero es más numeroso que el segundo. Hay 41 individuos con cerámica enterrados en 30 tumbas, y 29 individuos sin cerámica, inhumados en 20 tumbas. Esto da una relación de $58.5 \%$ de la población adscrita al primer caso y $41.4 \%$ al segundo.

La proporción entre los sexos en uno y otro caso muestra un cierto equilibrio para el conjunto con cerámica ( $48 \%$ varones y $51 \%$ mujeres); en

3 Sólo se han considerado en este artículo las piezas alfareras asociadas directamente con los ajuares funerarios, no así las que se encontraron formando parte del relleno de tumbas o en los espacios intertumbas. 


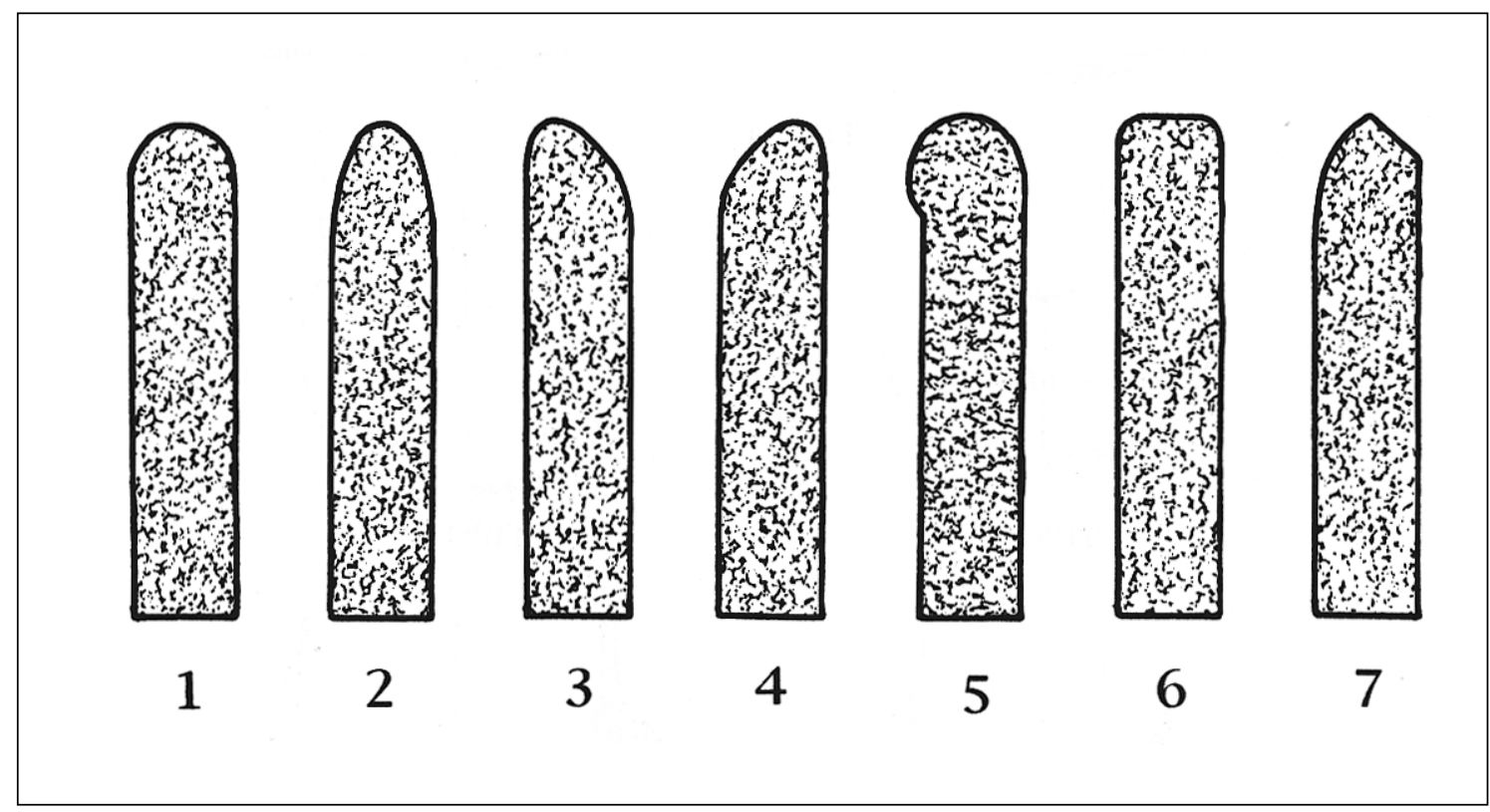

Figura 3. Tipología de labios de la cerámica de Coyo 3.

cambio, entre los sin cerámica hay un predominio de mujeres ( $40 \%$ varones y $60 \%$ mujeres). La edad de los hombres, tanto en el primer conjunto como en el segundo, da un promedio de 30-35 años y, en el caso de las mujeres, el promedio para ambos grupos es de 35-40 años.

De la clasificación de los 17 tipos alfareros se desprende que los que representan al sitio son los tipos 1,2 y 3 , con 25 vasijas $(52.0 \%$ del total de cerámicas), distribuidas en 18 tumbas. Los tipos 4 , $5,6,13,16$ y 17 se han mantenido como filiaciones indefinidas por su baja representatividad y por la falta de referentes; en total son 14 vasijas (29.1\%) distribuidas en 13 tumbas. Los tipos 7, 8, 9, 10, 11, 12,14 y 15 se manifiestan como evidentemente foráneos, con un total de nueve vasijas y un porcentaje en relación al total, de $18.7 \%$ (Figuras 9, 10 y 11). ${ }^{4}$ Estas nueve vasijas se encuentran distribuidas en siete tumbas, lo que equivale a $24.1 \%$ del total de enterratorios con cerámica. ${ }^{5}$

4 Además de éstas, hay dos ejemplares en el tipo 1 que, por sus discrepancias con la mayoría de su tipo, podrían ser también foráneos, lo que subiría el porcentaje de estos últimos a $22.9 \%$ o aún sobre este valor, si es que algunas de las piezas de filiación indefinida fueran también foráneas.

5 El análisis petrográfico del recipiente 14143 de la tumba 48, de posible procedencia de la región Yavi, acusó presencia de circón en su pasta, lo que resulta sugerente como elementotraza para un seguimiento de foraneidad.
Determinados tipos cerámicos aparecen interrelacionados de tal manera en los contextos funerarios que nos ha permitido definir asociaciones recurrentes: 1) asociación a: agrupa los tipos 1, 5, 7, 16 y $15 ; 2)$ asociación b: agrupa los tipos 2,3 y 6 ; 3) asociaciones únicas: comprende dos subgrupos independientes, por un lado 8 y 14, por otro, 9 y 12 ; 4) piezas sin asociación: los tipos 4, 10, 14 y 17 se presentan en forma aislada y como contextos alfareros únicos.

\section{Calabazas}

Las calabazas se encuentran prácticamente ausentes, probablemente debido a los problemas de mala preservación del material orgánico de este sitio. Hay solamente dos ejemplares muy destruidos y que no presentaron condiciones de análisis; ambos objetos se hallaron con individuos del sexo femenino. Evidencias en tumbas 23 y 30.

\section{Cestería}

Esta categoría presenta el mismo problema de preservación de las calabazas. Se registran solamente dos evidencias en forma de fragmentos, a partir de las cuales se pudo determinar que la técnica de fabricación fue la coiled. En otros casos, sólo se advertían restos muy deleznables de fibras 

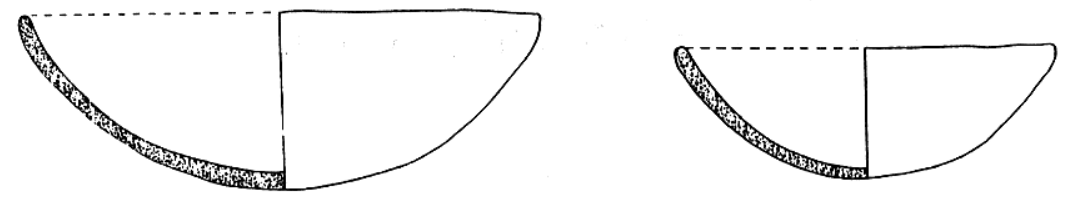

TIPO 1

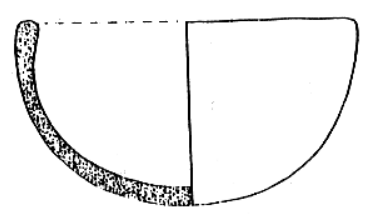

TIPO 2

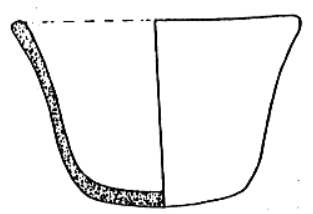

TIPO 4
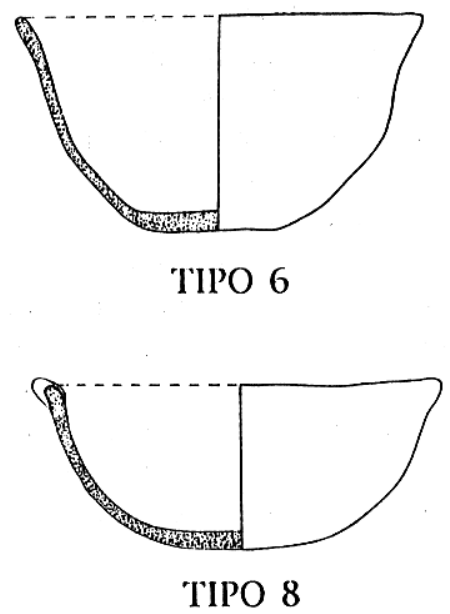

TIPO 8

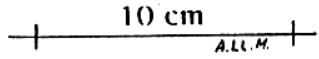

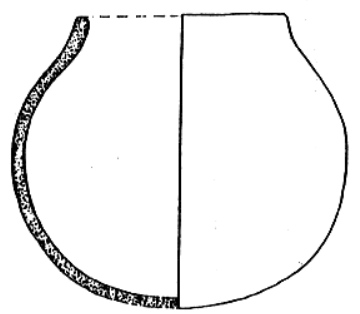

TIPO 3
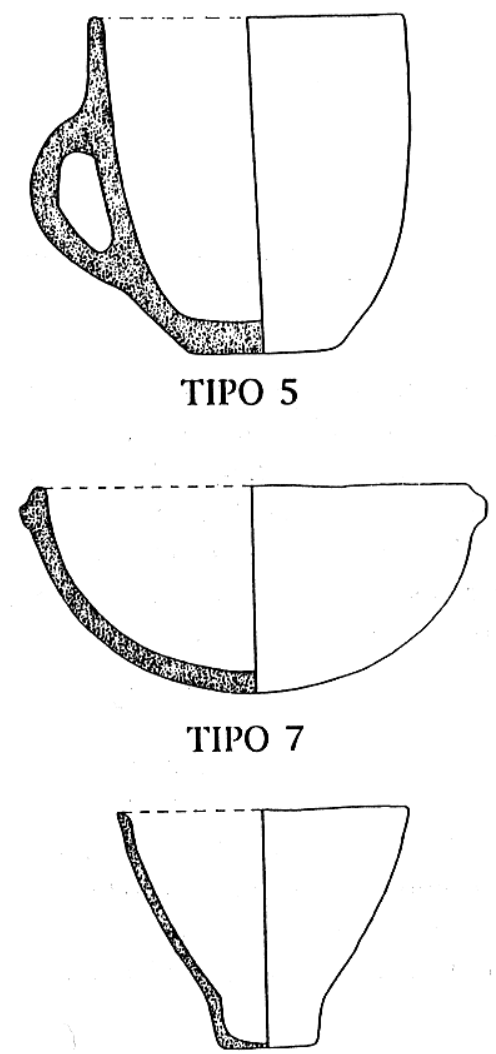

TIPO 9

Figura 4. Morfología cerámica de Coyo 3: Tipos 1 a 9. 


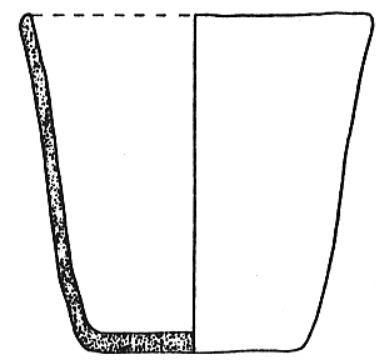

TIPO 10

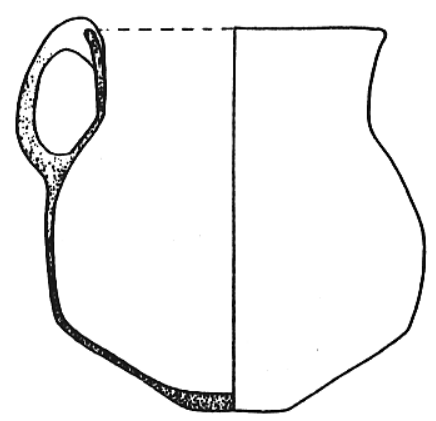

TIPO 12

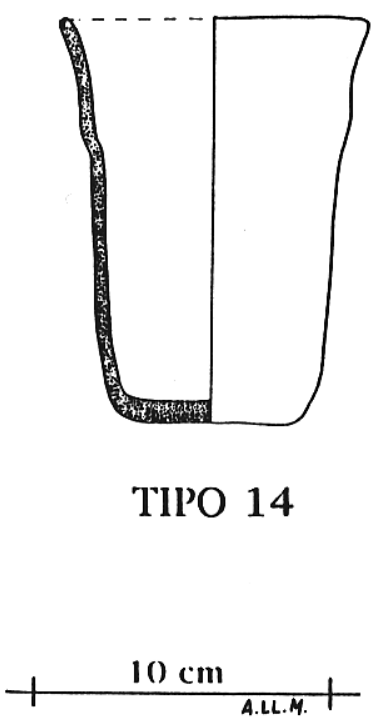

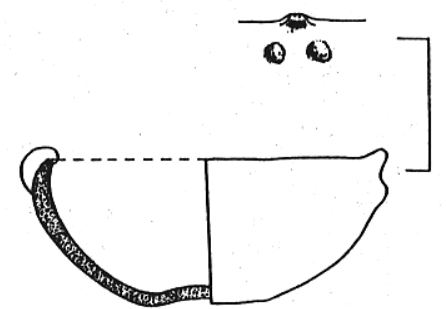

TIPO 11

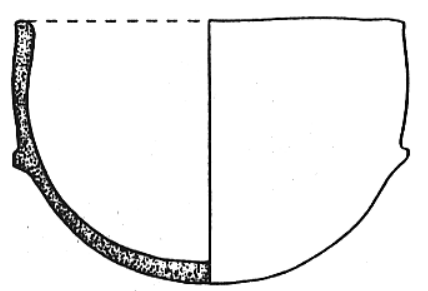

TIPO 13

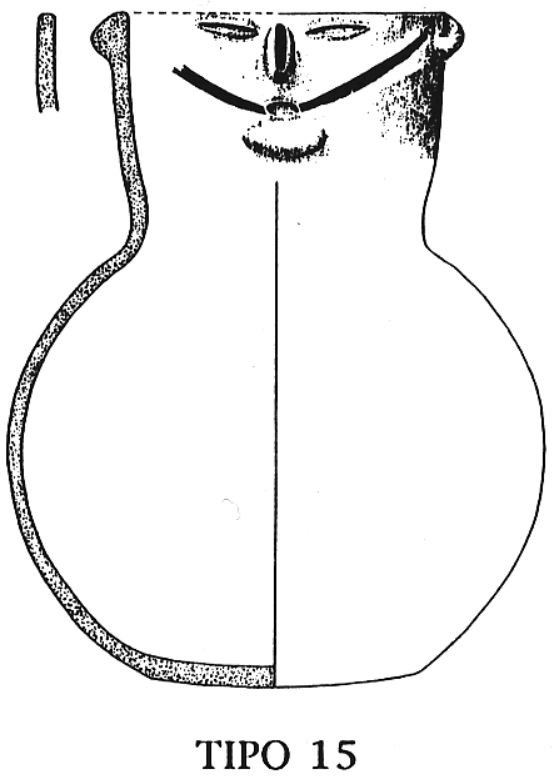

Figura 5. Morfología cerámica de Coyo 3: Tipos 10 a 15. 


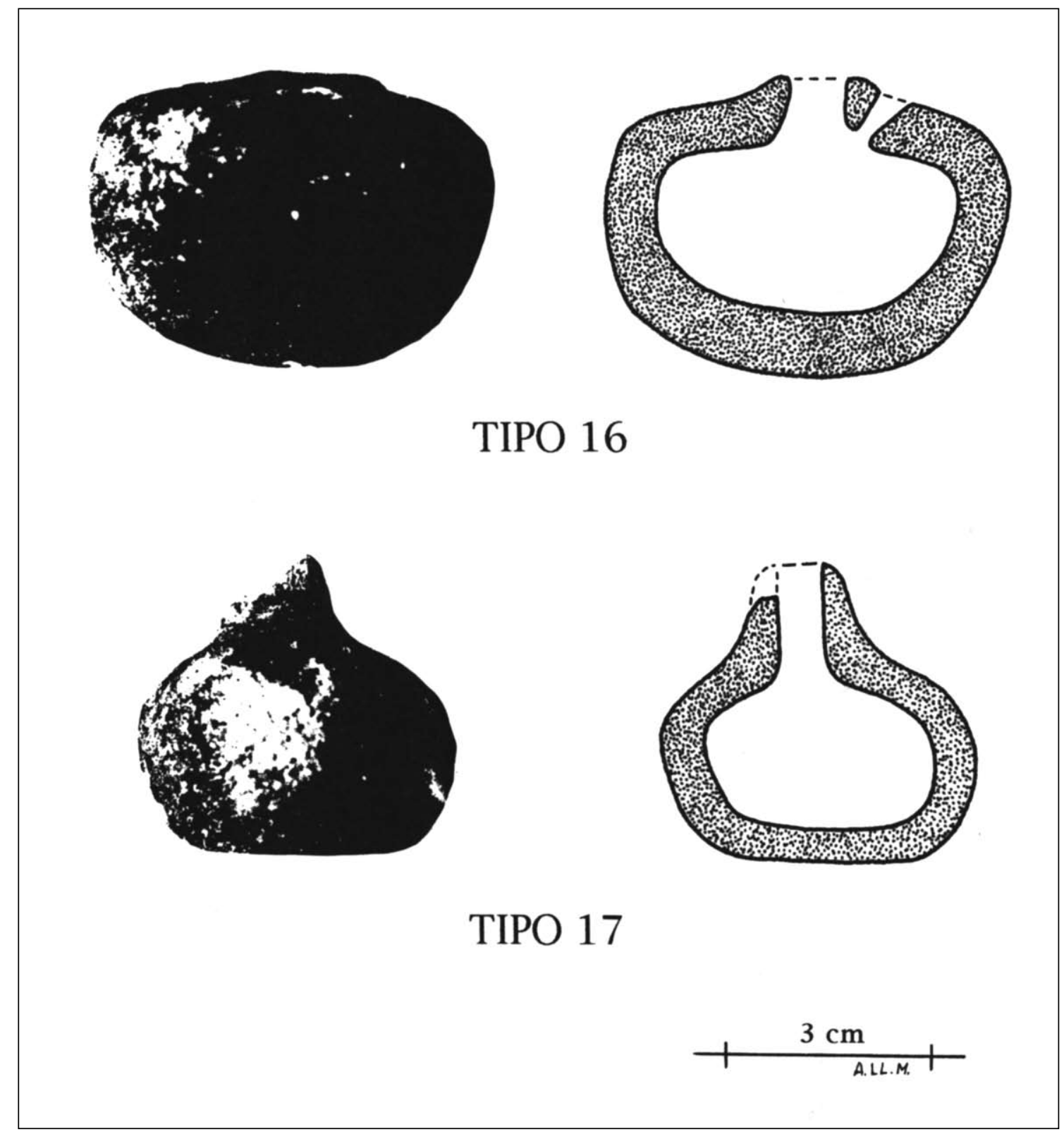

Figura 6. Morfología cerámica Coyo 3: Tipos 16 y 17.

entramadas o solamente por la impronta del tejido en la concreción del terreno. Son 10 registros en ocho tumbas y se asociaban con cuatro hombres (uno de los cuales tenía tres ejemplares), dos mujeres y dos niños. Evidencias en tumbas 6, 36, 40, $42,43,44,48$ y 50 .

\section{Madera}

Los objetos confeccionados con este material fueron también afectados en forma importante por las malas condiciones de preservación del sitio, a pesar de lo cual se logró rescatar la siguiente información:

Tabletas. Seis de estos artefactos se encontraban totalmente destruidos, lográndose apenas detectar su presencia en las tumbas. La séptima tableta se encontraba en pésimo estado de conservación y fue consolidada en terreno. Está constituida de una caja rectangular excavada y de un mango angosto; sin decoración (Figura 12b). Todas las tabletas se 


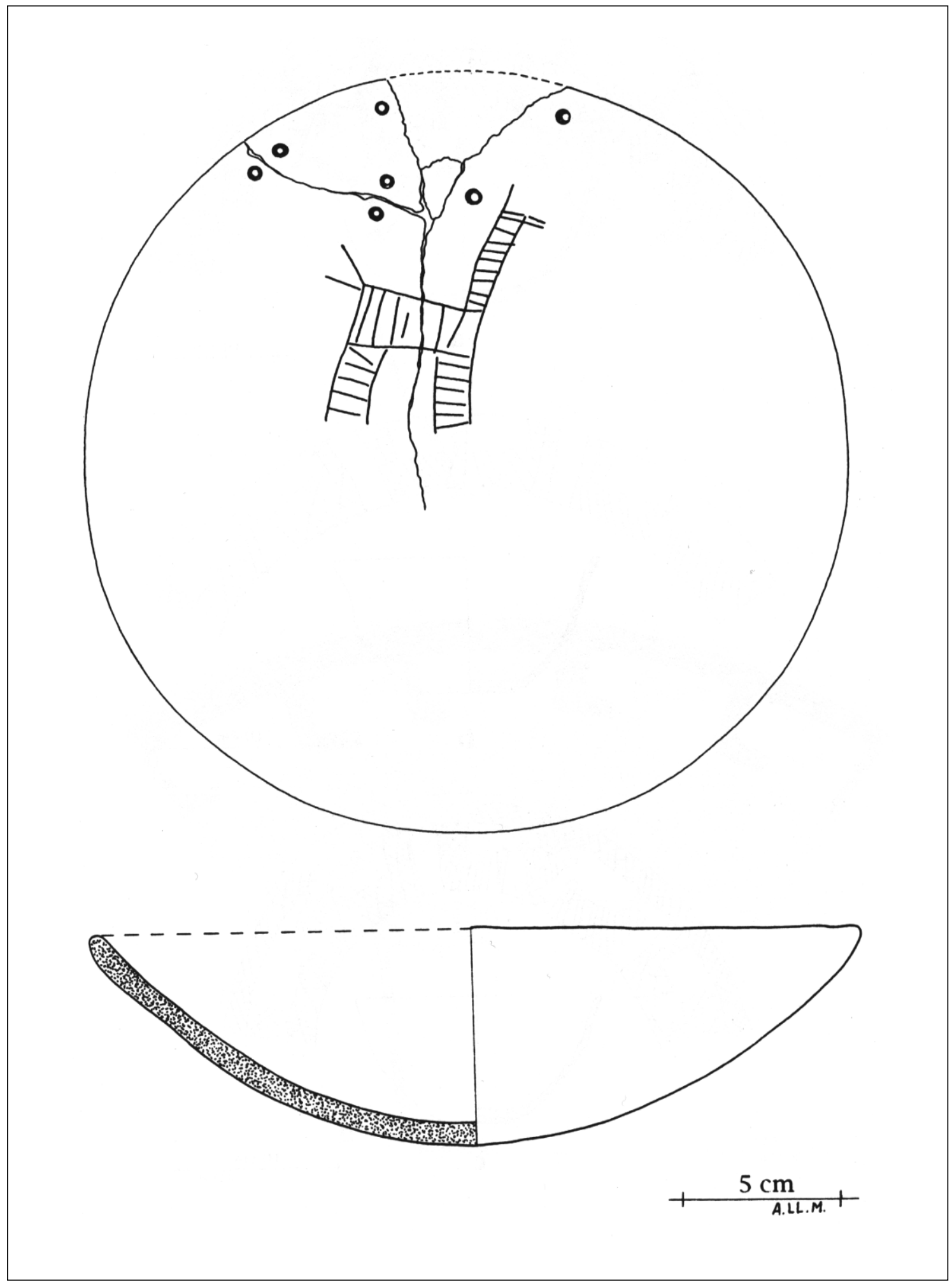

Figura 7. Cerámica del Tipo 1 con camélido inciso postcocción (13375). 

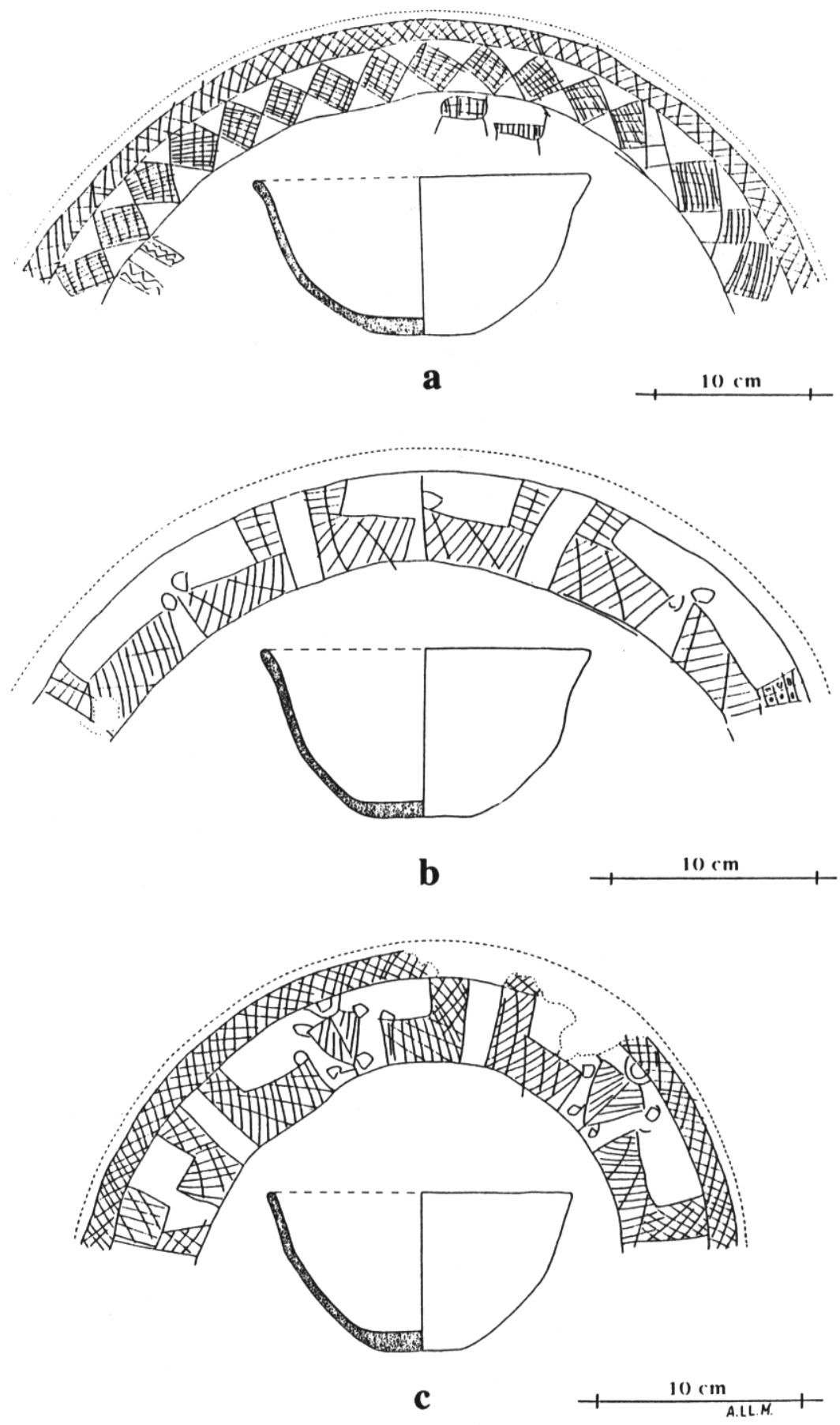

Figura 8. Piezas cerámicas del Tipo 6 con diseños grabados (a: 13686, b: 13727 y c: 13729). 

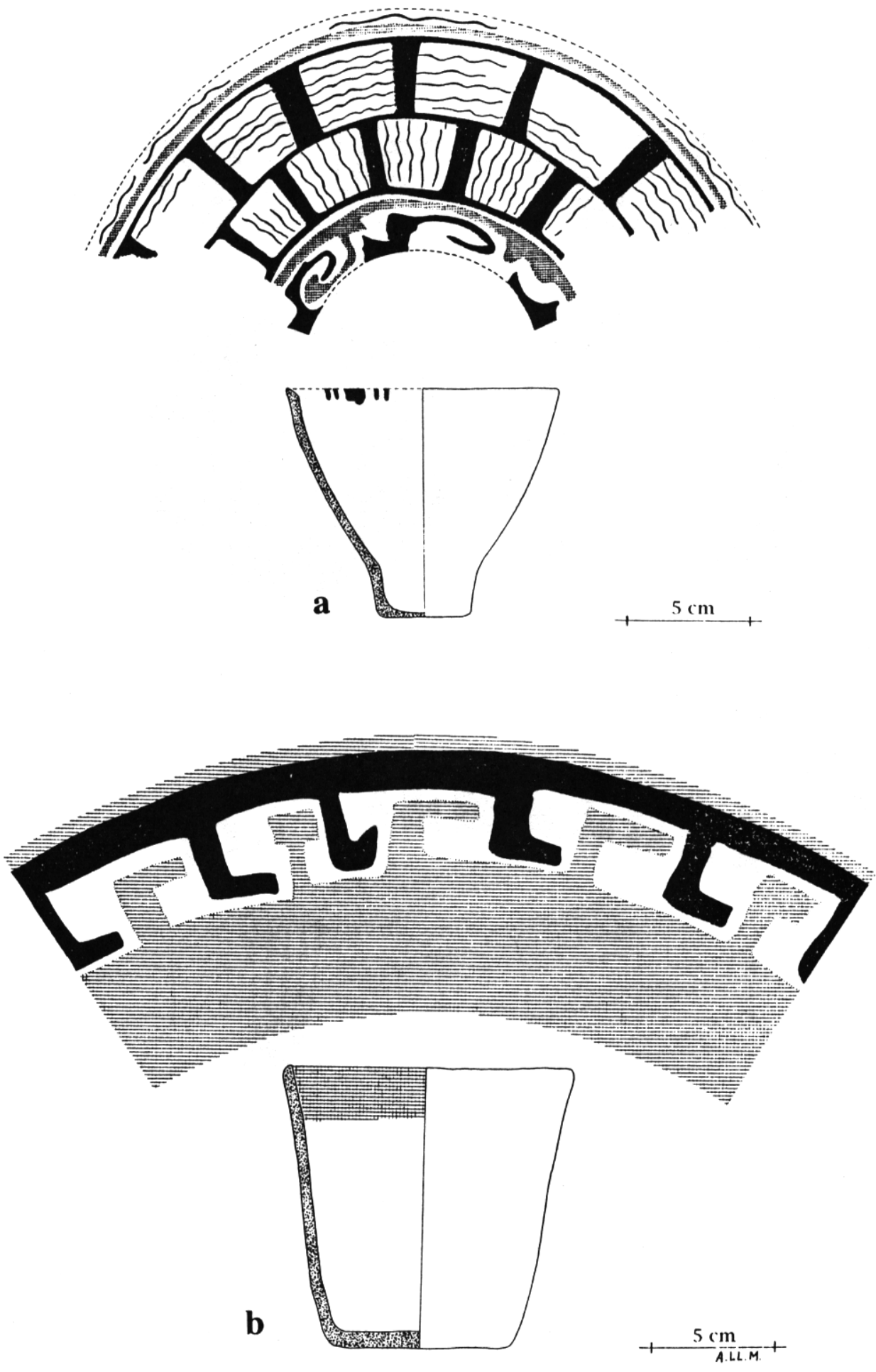

Figura 9. Alfarería foránea con decoración pintada. Tipo 9 (a: 13668) y Tipo 10 (b: 13700). 

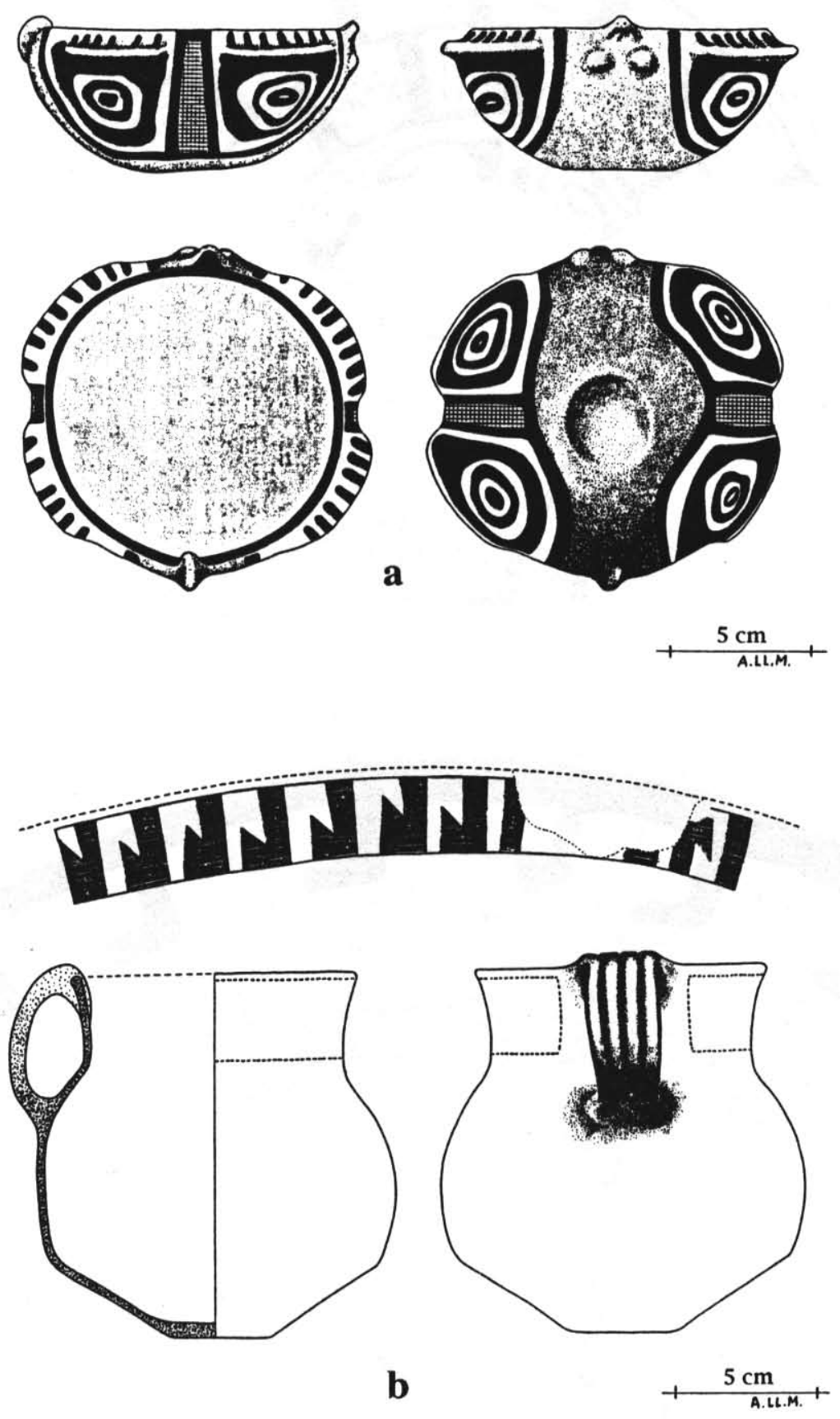

Figura 10. Alfarería foránea. Tipo 11 con decoración pintada de filiación Aguada (a: 13376) y Tipo 12 con decoración grabada (b: 13667).

encontraban con individuos del sexo masculino en siete tumbas, lo que significa que $28 \%$ de los hombres portaba este elemento en su ajuar funerario. Con excepción de una tableta, todas las demás estaban acompañadas de otros elementos del complejo del alucinógeno, como tubos y cucharas o espátulas de madera o de hueso. Evidencias en tumbas $31,35,37,44,46,50$ y 51 . 

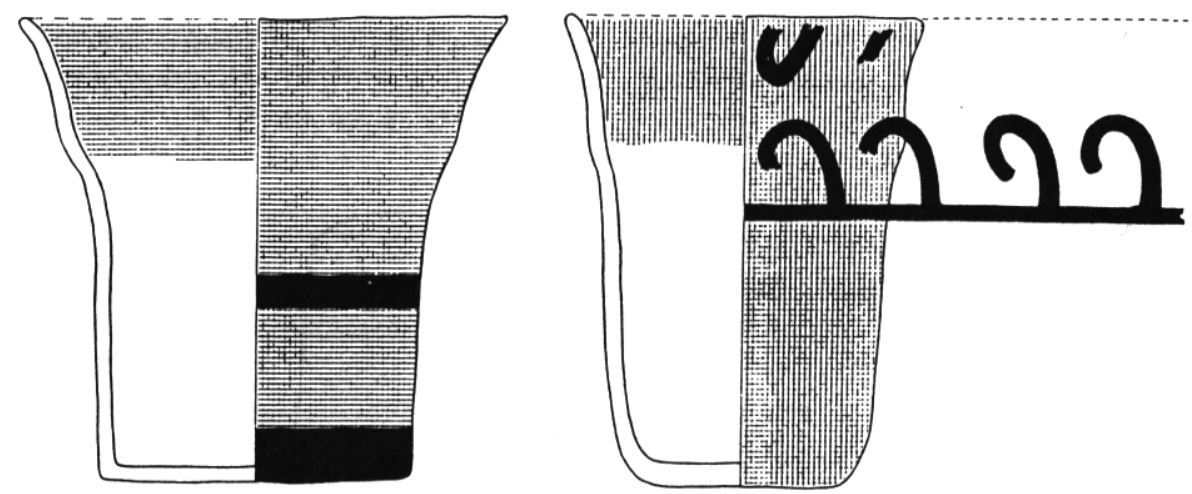

$\mathbf{a}$
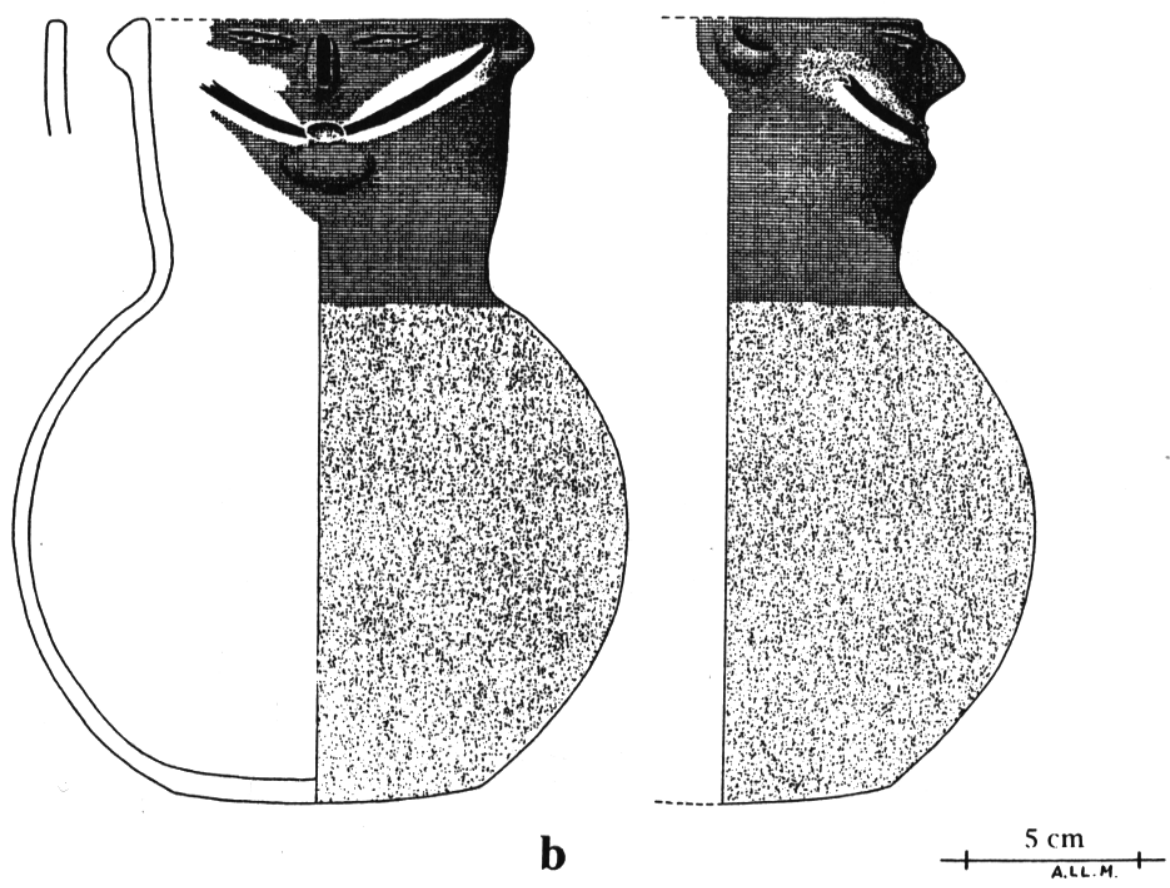

Figura 11. Alfarería foránea. Tipo 14 de filiación Tiwanaku Decadente (a: 13345 y 13226) y Tipo 15 de posible filiación Yavi Temprano (b: 14.143).

Tubos. Se encontraron restos sin condición de análisis de dos tubos de madera con individuos masculinos (8\%), uno de ellos asociado con tabletas y el otro, con una cuchara. Evidencias en tumbas 35 y 46.

Cucharas. Se registran dos cucharas de madera, en mal estado de conservación, faltando partes de la pala y del mango. Presentan palas excavadas, una de forma ovalada y la otra, piriforme, sin decoración. Ambas en entierros masculinos (Figura 15 e y f). Evidencias en tumbas 16 y 35 .

Recipientes. De los tres registrados, sólo uno pudo ser analizado; presenta cuerpo globular, cuello recto y labio sobresaliente (Figura 12d). Es de pequeñas 
dimensiones. Todos estos recipientes se encontraron en tumbas masculinas. Dos se asociaban con tabletas. Evidencias en tumbas 5, 31 y 37.

Torteras. Fueron encontradas seis torteras de madera, todas asociadas con mujeres. Cinco de ellas eran parte de un mismo conjunto funerario, el que se integraba, además, una cerámica local y una foránea, un jarrito de plata, colorante rojo y una calabaza (con la mujer en decúbito lateral); dos de ellas pueden ser adscritas al Grupo B, tipo 2, subtipo 1 de la tipología hecha para Quitor 6 (Costa 1988) (Figura 15c). Las otras tres se encuentran en forma fragmentaria, dos con sección circular; una de ellas presenta decoración consistente en cinco líneas incisas que circundan la pieza (Figura 15a). De la tercera se conserva poco más que el orificio central. La sexta tortera es tabuliforme, de forma rectangular con decoración de muescas a cada lado de los extremos de la pieza (Figura 15b). La séptima tortera es descrita bajo el ítem "concha" (Figura 15d). Evidencias en tumbas 23 y 35.

Arcos. Se encontraron restos de arcos en dos tumbas masculinas, asociados con astiles. Evidencias en tumbas 5 y 22 .

Astiles. Fueron cuatro evidencias de astiles en tumbas masculinas; en un caso estuvo asociado a arco. Evidencias en tumbas 3, 5, 14 y 16.

Espinas de cactus. Dos registros acompañando a individuos masculinos. Evidencias en tumbas 9 y 16.

Gancho de atalaje. Se encontró uno solo, en tumba masculina. Evidencia en tumba 33.

\section{Hueso}

Tubos. Se encontraron cinco tubos de hueso distribuidos en tres tumbas masculinas y en una de un adulto al que no fue posible asignar sexo. Fueron elaborados en huesos largos de aves de diferentes diámetros. Algunos se encontraban fracturados y en diferentes estados de preservación. Uno de ellos presentaba decoración consistente en franjas achuradas con alternancia de bandas rectas y en zigzag; componían un contexto junto con tableta (Figura 12a). Uno de los otros tubos presentaba una boquilla de madera casi desintegrada, además de la tableta, un recipiente de madera y cuchara de hueso. Otro de ellos, sin decoración, se asociaba a cinco cucharas/espátulas de hueso y un retocador de hueso. Evidencias en tumbas 4, 9, 31 y 34.

Cucharas/espátulas. Incluimos los dos tipos de objetos puesto que lo único que los diferencia definitivamente es la forma de la pala, la que muchas veces se encontraba ausente de la pieza, imposibilitando la determinación de su función (Figuras 13 y 14). Son 11 de estos instrumentos, todos encontrados con varones, distribuidos en siete tumbas; una de ellas presentaba un conjunto de cinco ejemplares, además de un tubo. La pieza 13559 parece ser una cuchara doble; en un extremo hay una pala espatulada ancha, de forma irregular que en algún momento se quebró pero fue reutilizada, puliéndose los bordes fracturados. En la otra extremidad de la pieza hay otra pala angosta, excavada. En el mango y en la pala ancha hay pulimento por uso (Figura 13a). La pieza 13784 es una cucharilla con pala recortada y rebajada, separada visualmente del mango por una incisión profunda que circunda la pieza. Sobre la cara anterior del mango hay una serie de incisiones paralelas que parten de los bordes pero que no se encuentran al centro. El extremo proximal está fracturado, faltando parte del mango (Figura 13b). La cuchara 13716 presenta pala excavada en el reverso del hueso largo de animal. Está decorada con franjas achuradas, dispuestas transversalmente al mango; estas franjas se alternan con otras lisas y van desde el borde de la pala hasta la extremidad del mango, por la cara posterior del objeto (Figura 14c). Aprovechando la curvatura natural del hueso de animal, se fabricó una cuchara (13723); en la extremidad proximal del mismo se talló una cara humana con un tocado de plumas (Figura 14a). En las extremidades de las tres plumas se practicaron perforaciones circulares como elementos decorativos; además, hay tres incisiones en los bordes superiores e incisión en "V" en la pluma central. El tocado es separado visualmente de la cara por un tallado horizontal. La cara misma es solamente insinuada por el relieve de la nariz y una pequeña raya horizontal por debajo de la misma, a modo de boca. El óvalo de la cara está representado por una línea incisa que delimita el contorno de la mandíbula (Figura 14b). La extremidad distal de la cuchara es redondeada y la pala está groseramente excavada. A $6.4 \mathrm{~cm}$ de esta extremidad y sobre la cara anterior del mango hay una decoración en forma de "cuenta de collar", esto es, un orificio 


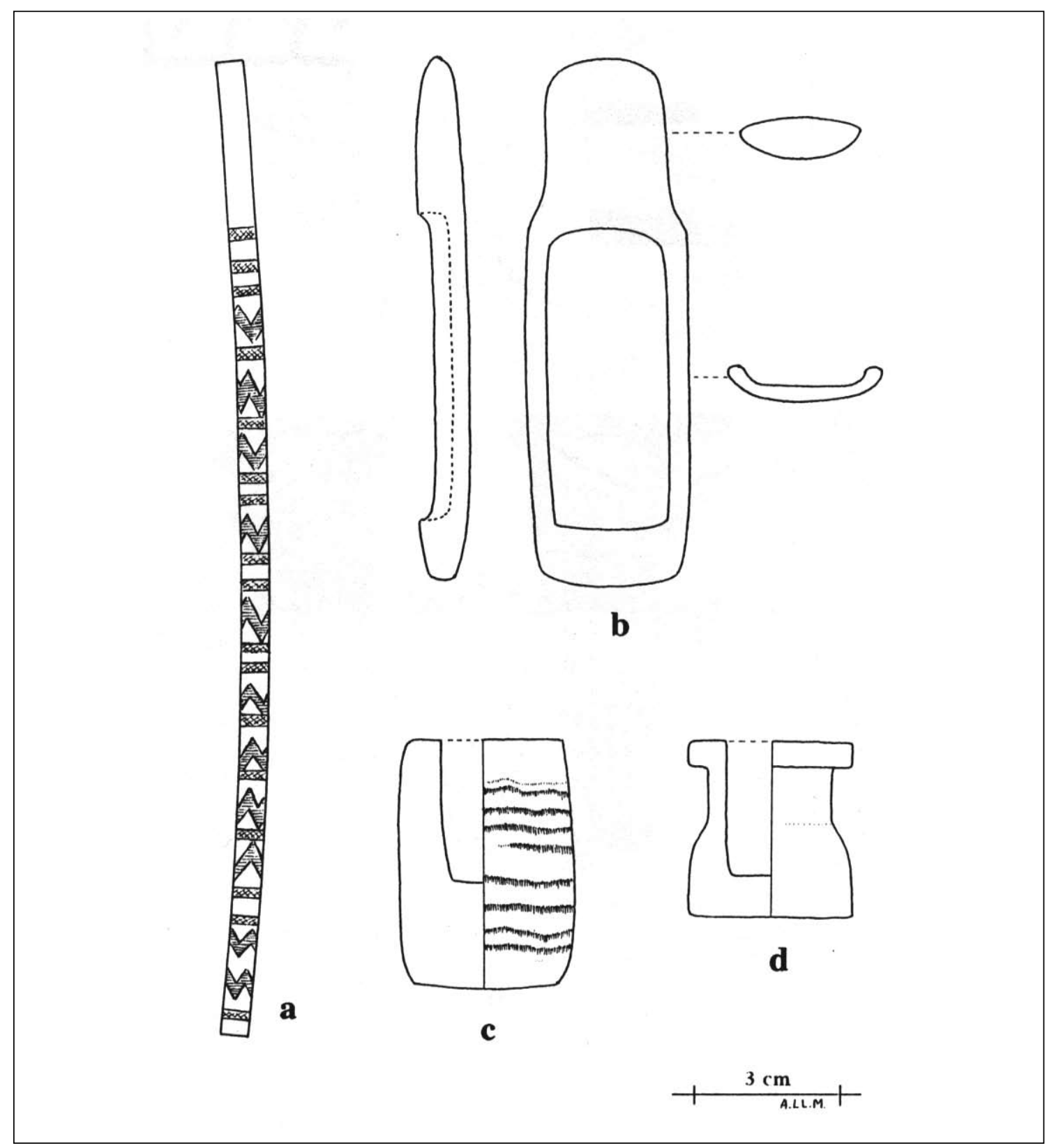

Figura 12. a) Tubo inhalador de hueso (13271); b) Tableta para alucinógeno (13799); c) Morterito de yeso natural (13216); d) Morterito de madera (13642).

central poco profundo rodeado por un círculo; este mismo motivo se encuentra en el dorso de la cuchara, a $2.1 \mathrm{~cm}$. del borde. La pieza 13245 es un fragmento de espátula consistente en una pala rectangular que presenta dos aletas en la unión con el mango, como única decoración (Figura 13d). Las demás no presentan decoración; hay una con pala de forma cuadrangular, una de forma rectangular $y$ dos, ovaladas (Figura 13c). Evidencias en tumbas $1,9,31,35,37,42,44$ у 50 .

Retocador. Un posible retocador, encontrado en una tumba masculina. Se trata del fragmento de un instrumento con un extremo aguzado (al cual le faltan pedazos); a partir de un acinturamiento se construyó una punta angosta y alargada como 


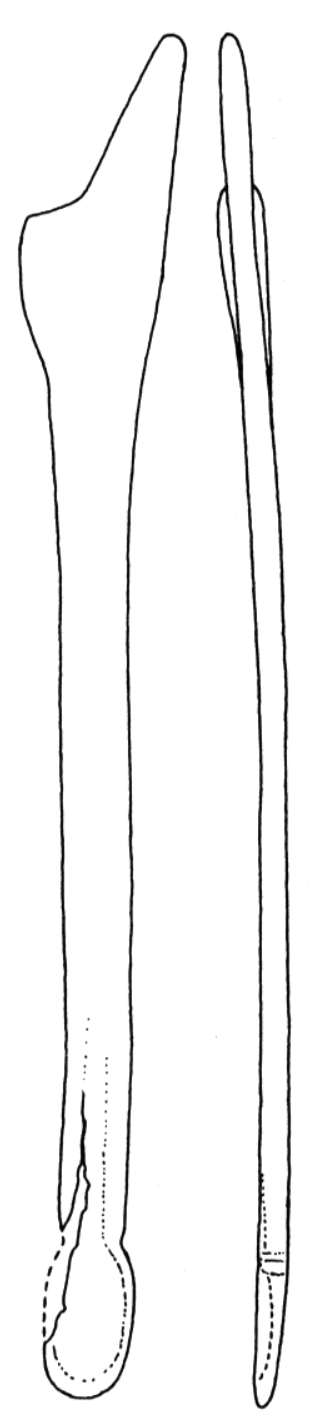

a
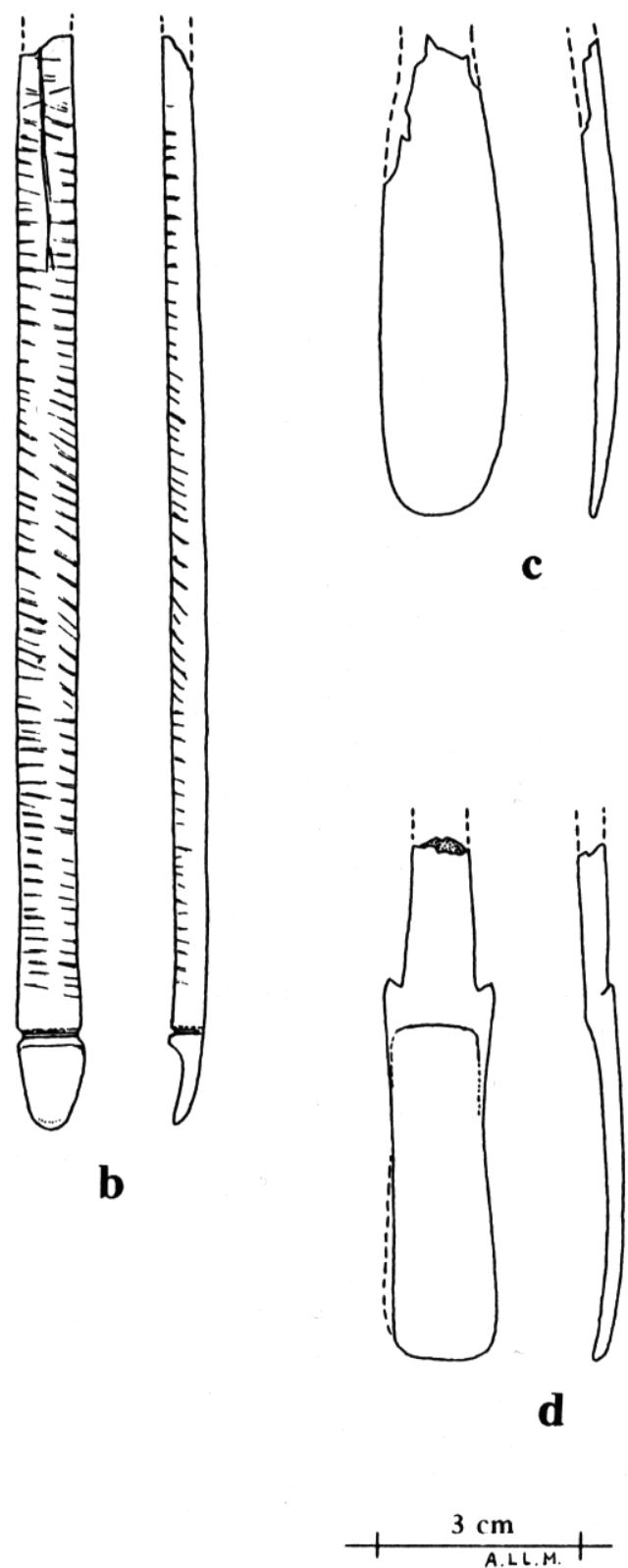

Figura 13. a-b) Cucharillas de hueso (13559 y 13784); c-d) Espátulas de hueso (13252 y 13245). 

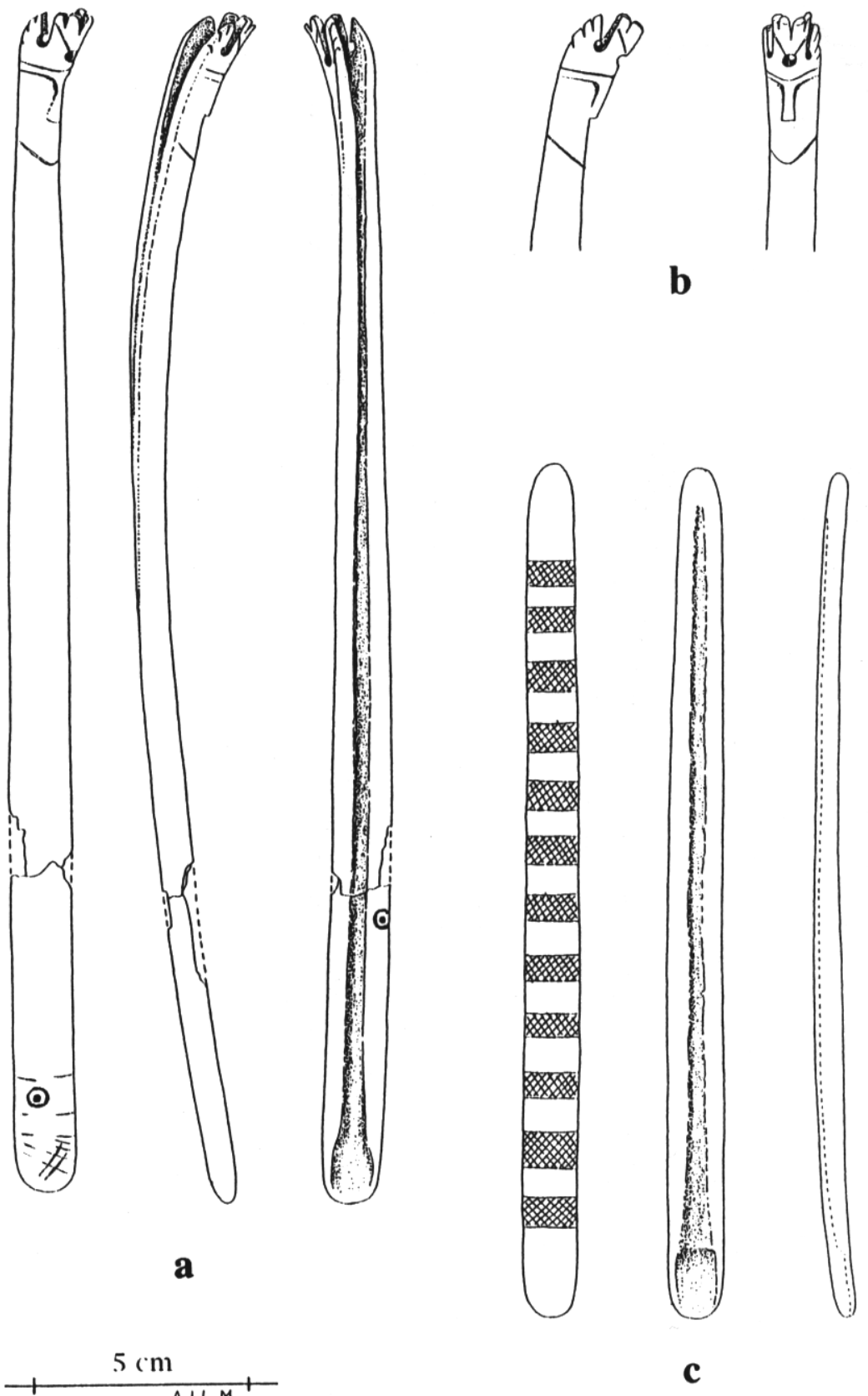

Figura 14. a-b) Cucharillas de hueso (13559 y 13784); c-d) Espátulas de hueso (13252 y 13245). 

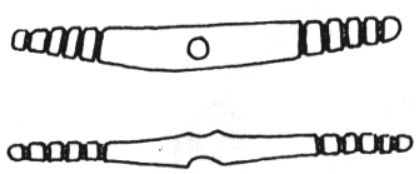

a
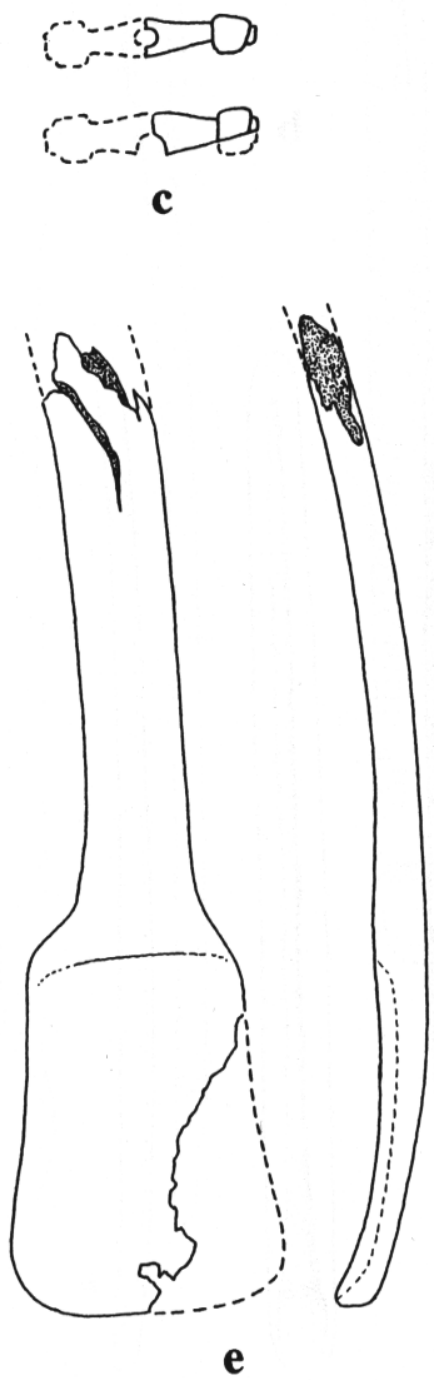
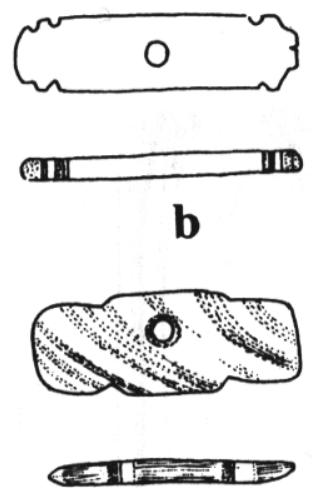

d
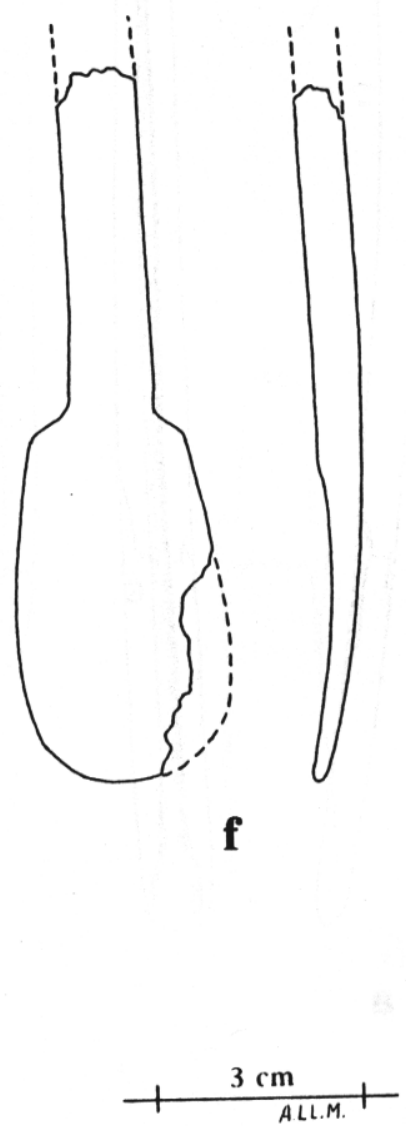

Figura 15. a-c) Torteras de madera (13619, 13627 y 13683); d) Tortera de concha de Choromytilus (13584); e) Cuchara de madera (13295); f) Cuchara de hueso (13246). 
un punzón. Hay un intenso pulimiento en todo el borde de la curvatura cóncava de la pieza, posiblemente por presión de la mano en la utilización del instrumento. Evidencia en tumba 9.

Metal

Anillos. Encontramos cuatro anillos de alambre delgado de cobre, fragmentados, en un cuerpo femenino. Evidencia en tumba 45.

Cintillo de plata. En una tumba femenina. Es de forma laminar, mide $57.5 \mathrm{~cm}$ de largo y $3 \mathrm{~cm}$ de ancho y $0.1 \mathrm{~cm}$ de espesor. Muy fragmentado. Evidencia en tumba 11.

Disco de oro. Se encontraba en una tumba de hombre, mujer y niño, directamente asociado al cuerpo del varón. El disco está hecho en una lámina circular que mide $15 \mathrm{~cm}$ de diámetro, con un orificio central de $1.5 \mathrm{~cm}$ de diámetro. Muy fragmentado. Evidencia en tumba 35.

Discos de plata. Once de ellos aparecieron en una tumba masculina, asociada al único gancho de atalaje encontrado en este sitio. Son laminares, tienen en promedio $3 \mathrm{~cm}$ de diámetro, con perforación central de $0.8 \mathrm{~cm}$ y espesor de $0.01 \mathrm{~cm}$. Cerca del borde hay un pequeño orificio (¿para colgar?). La otra, también con un varón, presenta las mismas características de las anteriores, siendo un poco más pequeña $(2.7 \mathrm{~cm}$ de diámetro, orificio central de $0.6 \mathrm{~cm}$ ); presenta igualmente la perforación cerca del borde. Se hizo analizar una muestra del metal, encontrándose que está compuesto de: Ag 25.17; Fe 0.44; Cu 0.22 y Zn 0.058. Evidencias en tumbas 6 y 33 .

Jarro de plata (miniatura). Asociado al individuo femenino que presenta la manera atípica de depositación del cuerpo de la tumba, en decúbito lateral, y con el conjunto de cinco torteras. Presenta base cóncava, cuerpo semiglobular, cuello restringido de bordes evertidos. Decoración en el centro del cuerpo en forma de carita humana repujada; se advierten nariz y cejas $3.4 \mathrm{~cm}$ del alto y $3 \mathrm{~cm}$ de diámetro total. Evidencia en tumba 23.

\section{Concha}

Tortera. En tumba femenina. Hecha en concha de Choromytilus chorus, de forma rectangular y de sección tabuliforme. Como decoración, a $1 \mathrm{~cm}$ de cada extremidad se practicó una muesca a cada lado de la pieza (Figura 15d). Evidencia en tumba 32.

Lítico

Hacha. Fue hallada una, en tumba de dos hombres; uno de ellos, con tableta, tubo, cuchara y el cuerpo de un camélido y el otro, con un tubo. El hacha se encontraba entre los dos cuerpos, a la altura de los hombros. Instrumento hecho en basalto, de forma rectangular, con aletas laterales en uno de los extremos (Figura 16e). Evidencia en tumba 44.

Martillos. Se encontraron ocho martillos hechos en piedra, todos en tumbas masculinas. De factura tosca y sin señales de uso, fueron elaborados en diferentes tipos de material lítico. Llama la atención que instrumentos de este tipo hayan sido construidos en piedras tan deleznables como la ignimbrita o la arenisca, sugiriendo una finalidad de ritual o simbólica para los mismos. Presentan formas irregulares que se aproximan al cilindro y al cono. Llevan una escotadura que circunda la pieza en una de las extremidades, para el amarre de la pieza al mango de madera. Tienen un promedio de $11 \mathrm{~cm}$ de largo, $5.3 \mathrm{~cm}$ de ancho y $3.7 \mathrm{~cm}$ de espesor (Figura 16a-d). Evidencias en tumbas 1, $6,18,35,41,42,49,51$.

Puntas. Hay 19 puntas líticas distribuidas en 10 tumbas, dos de las cuales, femeninas. Cinco de estos elementos aparecen juntos en una tumba. Todas tienen la forma triangular, tres de ellas alargadas, con aletas y pedúnculos. Están hechas en obsidiana blanca y negra, cuarzo rosado y gris. Evidencias en tumbas 1, 14, 31, 32, 33, 35, 37, 42, 44, 50.

Mortero. Fue encontrado un pequeño mortero de yeso, en una tumba de hombre y dos niños, asociado al varón y en un contexto de dos cerámicas locales, una cuchara de hueso, un martillo, dos puntas, algarrobo y camélido (Figura 12c). Evidencia en tumba 1.

Cuentas de collares o pulseras. Presentes en 25 enterratorios (52.9\%), es el material más abundante en el sitio; se presenta con $36.2 \% \quad(n=29)$ de los individuos, tanto varones como mujeres y niños. El $56 \%$ de los varones $(n=14)$ las tenía, así como $30 \%(\mathrm{n}=9)$ de las mujeres y $27.3 \%(\mathrm{n}=26)$ de los subadultos; queda evidenciado que eran los hombres los que, prioritariamente, llevaban este tipo de adorno. Fueron encontradas también preformas de 
cuentas, preferentemente con individuos masculinos $(\mathrm{n}=9 ; 36 \%)$; la asociación de preformas con dos mujeres no es segura puesto que correspondían a una tumba colectiva alterada de antiguo. Evidencias en tumbas $1,3,4,5,8,10,11,12,14,15,18,20$, $23,27,29,35,37,41,42,44,49,50$ y 51 .

Trozos de mineral de cobre. Hay 13 conjuntos de trozos de este mineral en otras tantas tumbas; siete hombres (28\%), cinco mujeres (16.7\%) y un subadulto (4.5\%) contaban con este elemento entre sus ofrendas. Evidencias en tumbas 6, 7, 10, 11, $12,14,17,20,27,35,37,41$ у 46.

\section{Esquirlas de mineral de cobre. Algunas veces este} material se presentaba esparcido en la tumba; en otras, se advertía que había estado contenido en una bolsa, aunque de ésta no quedaran evidencias. Las esquirlas, por lo general de muy pequeño tamaño, se asociaban a 11 hombres (44\%), tres mujeres $(10 \%)$ y un subadulto $(4.5 \%)$, en contextos de variada importancia; desde aquéllos con objetos del complejo alucinógeno y/o cerámicas locales o foráneas, hasta los que solamente presentaban elementos que pudiéramos considerar como pobres indicadores de estatus social. Evidencias en las tumbas $4,8,14,18,27,30,31,35,36,42,44$, 46,48 y 51 .

\section{Textiles y cordelería}

Por las condiciones de preservación del sitio, sólo se registraron evidencias de un gorro en una tumba masculina. Evidencia en tumba 16.

\section{Flora}

Aparte de las calabazas, consideradas como material artesanal, sólo se detectaron evidencias de maíz (Zea mais) en una tumba masculina y de algarrobo (Prosopis chilensis) con dos individuos masculinos y con una mujer. Evidencias en tumbas 35 y 30, respectivamente.

\section{Fauna}

Camélidos. Encontrados en 22 enterratorios, en cuatro de los cuales fue colocado el cuerpo completo del animal; estas últimas eran tumbas colectivas con la presencia de, por lo menos, un varón, al que los animales se asociaban más directamente; en las demás tumbas, solamente una o dos patas, y en una ocasión, un cráneo. Estas ofrendas eran colocadas solamente en tumbas de adultos y, en el caso de las patas, sin distinción de sexo. Este material se encontraba tanto en tumbas con cerámica como en las que este elemento estaba ausente; solamente tres de las tumbas con camélidos presentaban cerámica foránea pero en ningún caso, el animal completo. Evidencias en tumbas 1, 7, 8, 14, 17, $20,21,22,27,28,31,32,33,35,36,37,38,41$, $44,45,46$ у 48 .

Caracoles de agua dulce. Se identificaron 16 ejemplares de conchas pertenecientes al género Strophocheilus $s p$, algunas muy destruidas, acompañando a 14 individuos, entre ellos, 10 mujeres (33.3\%), dos hombres (8\%), uno de los cuales con dos conchas, y dos subadultos $(9.1 \%)$, uno con dos ejemplares. Seis de ellos servían de recipientes para pigmento rojo y estaban entre las ofrendas de cinco mujeres y la de un lactante. Evidencias en tumbas $2,11,21,28,30,32,35,36,40,41,45$, 47,48 y 49 .

\section{Miscelánea}

Tierras de color. Esta sustancia aparece en los colores rojo (el más frecuente), morado, ocre y en combinación rojo y negro, en nueve tumbas, asociada seis veces con mujeres $(20 \%)$ y tres con subadultos (13.6\%). Los hombres parecen estar excluidos de la posesión de este elemento. En cinco oportunidades (una de ellas con un subadulto), el colorante aparece en el interior de las conchas de Strophocheilus sp. Evidencias en tumbas 17, 23, $25,30,36,40,45,44,47,48$ y 49.

\section{Material biológico humano}

\section{Material y métodos}

La muestra se compone de 80 individuos, en muy diverso estado de preservación: desde bueno hasta muy malo. Para la estimación del sexo consideramos la morfología pélvica y craneana (Bass 1971; Ubelaker 1978). En la determinación de la edad de los adultos empleamos los signos de maduración de la sínfisis pubiana (McKern y Stewart 1957; Gilbert y McKern 1973; Meindl et al. 1985), la sinostosis de las suturas craneanas (Meindl et al. 1985). Para los subadultos utilizamos la fusión de la sincodrosis esfenoccipital; la osificación y fusión de la epífisis; la calcificación y el estado de erupción dentaria (Ubelaker 1978). Los rasgos no-métricos fueron observados de acuerdo a Castro y Quevedo (1983). 


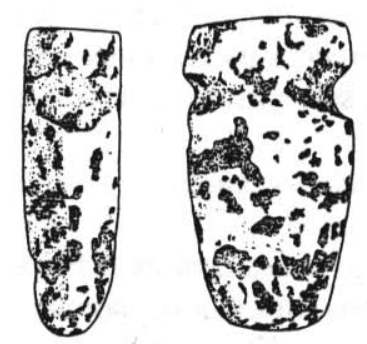

$\mathbf{a}$

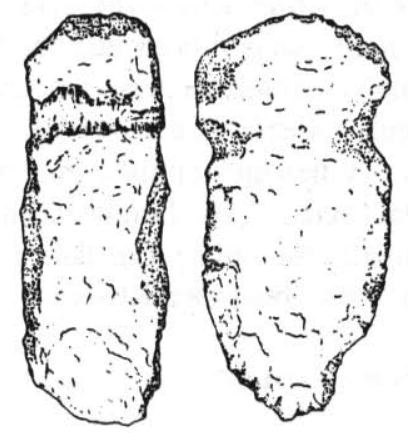

c
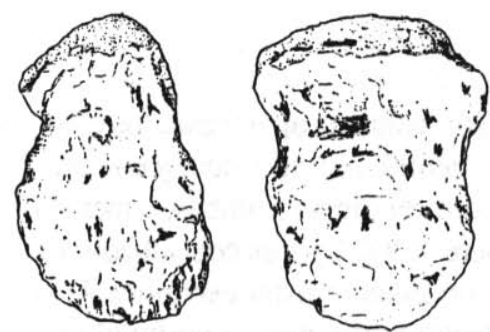

b
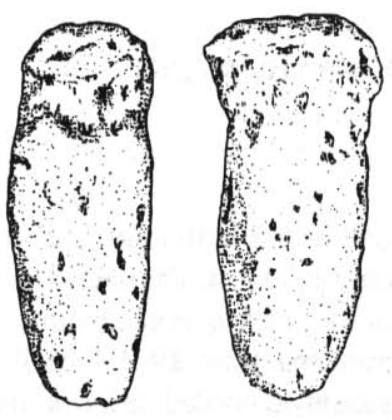

d
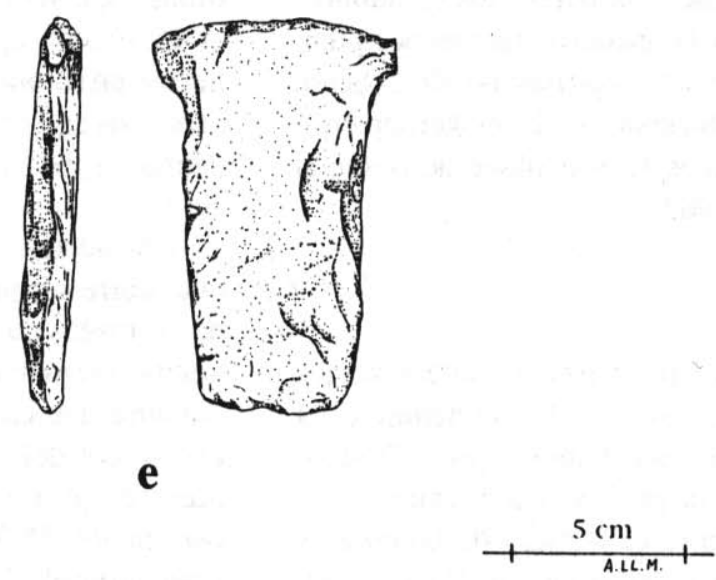

Figura 16. a-d) Cabezas líticas de martillos (13776, 13681, 13279 y 13797); e) Hoja lítica de hacha (13714).

\section{Paleodemografía}

Esta población se compone de 55 adultos, de los cuales 25 son masculinos y 30 femeninos, 24 subadultos (incluyendo dos fetos) y tres individuos adultos a los que no fue posible determinar el sexo.
Hay un equilibrio entre el número de hombres y mujeres enterrados en este cementerio. Para la clasificación por edades, se consideró fajas etarias de cinco años, desde 0 hasta más de 55 años, encontrándose que todas las fajas etarias están representadas en el sitio. 
El número de individuos de este sitio es insuficiente para realizar un estudio paleodemográfico adecuado, pero, en general, observamos que la mortalidad de niños es muy alta entre el nacimiento y los cinco años de edad (23.8\%); los individuos que sobrepasan esa etapa de la vida tienen buenas posibilidades de vivir hasta los 35-39 (20\%) y los 40-44 años (13.8\%). El número de decesos es parejo para los dos sexos, excepto que las mujeres viven más, habiendo tres que sobrepasaron los 55 años de edad.

\section{Deformación craneana}

Se verifica una alta proporción de cráneos deformados en este sitio, tanto de hombres como de mujeres. En un total de 42 individuos ( 21 mujeres, 17 hombres y cuatro subadultos), 37 están deformados $(88.1 \%)$, con porcentajes parejos para ambos sexos (18\% femeninos y $16 \%$ masculinos). Hay solamente cinco cráneos sin deformación en toda la población (11.9\%; tres mujeres, un hombre y un subadulto). El tipo de deformación craneana masivamente mayoritaria es la tabular erecta, con $94.5 \%$ (17 mujeres, 15 hombres y tres subadultos); uno con deformación circular erecta (2.7\%; hombre), y uno con circular oblicua (2.7\%; mujer). Los demás cráneos no presentan condiciones de análisis.

\section{Rasgos no métricos}

Hay una alta incidencia de estos rasgos en la población, siendo que el $100 \%$ de los individuos lo presenta. Los rasgos más frecuentes son los agujeros orbitales, con $47.7 \%$ y los surcos del frontal, con $46.5 \%$; los agujeros emisarios etmoidales y los huesos en sutura lambdoidal alcanzan $37.2 \%$ y $36 \%$. Los agujeros infraorbitales llegan a $30.2 \%$; los demás rasgos están por debajo de $30 \%$ de ocurrencia.

Considerando los sexos por separado se observa una preferencia sexual en la presentación de los rasgos no métricos en Coyo 3 puesto que los hombres siguen aproximadamente la pauta anterior, mientras que las mujeres difieren ostensiblemente. Los surcos del frontal entre ellas tienen $44.7 \%$, mientras que los huesos en sutura lambdoidal empinan en 55.3\%. El agujero timpánico, que se presenta en $15.2 \%$ de los hombres, está presente en $44.7 \%$ de las mujeres. Por último, el agujero emisario etmoidal derecho tiene una representación femenina de $47.4 \%$, contra $26.1 \%$ en los hombres; el mismo rasgo, al lado izquierdo, aparece en $36.8 \%$ de las mujeres, contra $30.4 \%$ de los hombres.

\section{Paleopatología general y traumatismo}

Hiperostosis porótica. En situaciones de carencia de hierro en el organismo, a consecuencia de inadecuación de la dieta, ocurre la formación de porosidades en la tabla externa de los huesos del cráneo y en el techo de las órbitas. De los 22 individuos en condiciones de ser examinados, cinco mujeres $(22.7 \%)$, tres hombres $(13.6 \%)$ y cuatro niños $(28.6 \%)$ mostraron evidencias de esta alteración ósea; las cribas orbitarias, específicamente, aparecieron en dos niños, dos hombres y dos mujeres $y$, excepto en una mujer, todas estaban en la etapa activa de formación. Ello nos lleva a sospechar de una dieta no equilibrada para estos individuos, los que representan $14.6 \%$ del total de la población.

Hipoplasia del esmalte dentario. Durante el proceso de formación de la corona de los dientes puede ocurrir una amelogénesis imperfecta, atribuida a etapas de mala nutrición y/o de enfermedades durante la infancia (Wing y Brown 1979), lo que se manifiesta en forma de surcos e irregularidades en la superficie del esmalte. La intensa pérdida de piezas dentarias durante la vida de los individuos y la ocurrencia de caries y de desgaste dental, que se discute más adelante, perjudican en forma importante este examen. Fueron examinados los dientes de 44 adultos y 14 niños (72.5\% de la muestra total). Se encontró que $27.6 \%(\mathrm{n}=16)$ muestra hipoplasia del esmalte dentario; $36.4 \%$ de los hombres y $27.3 \%$ de las mujeres y los subadultos tienen $14.3 \%$ de representación.

Infecciones inespecíficas. Sin importar la causa específica de las infecciones, se analizó su incidencia en esta población, partiéndose de la premisa de que un organismo debilitado por la carencia dietaria es fácil huésped de elementos patógenos. Fueron examinados 25 hombres, 25 mujeres y 18 niños, considerando la periostitis y la osteomielitis, tanto localizadas como generalizadas. Estos tipos de evidencias implican grados de comprometimiento puesto que, mientras la periostitis afecta al hueso solamente en su periferia, la osteomielitis ataca el interior del mismo. Las infecciones periapicales (ver más adelante) fueron consideradas como osteomielitis (generalizada, si comprometía más del tercio de las piezas dentales). Se encontró a ocho mujeres (32\%), 11 hombres (44\%) y dos subadultos 
(11.1\%) con este tipo de afección. Lo más común fue la periostitis generalizada, en cuatro hombres, seis mujeres y dos subadultos $(57.1 \%)$. Le sigue la periostitis localizada (42.9\%), en cinco hombres y cuatro mujeres. La osteomielitis localizada ocurrió en nueve individuos (42.9\%); cuatro hombres y cinco mujeres. La osteomielitis generalizada se verificó en una mujer (4.8\%).

En cuanto a las regiones del cuerpo más afectadas, la periostitis aparece preferentemente en las piernas (13 casos) y en las costillas de tres adultos; en el caso de una mujer de este último grupo, la infección se relaciona con la fractura de una costilla. Le siguen los brazos (cuatro casos), uno de ellos relacionado con una fractura. Aparece también en la pelvis de una mujer que presenta luxación de la cadera, asociada con ese fenómeno. De las dos mujeres que presentan periostitis en el cráneo, una es generalizada y probablemente relacionada con alguna herida externa y la otra, localizada, se asocia con un golpe en el frontal; hay dos hombres con periostitis localizada en el cráneo. La osteomielitis aparece en cuatro hombres y en cuatro mujeres, debidas a infecciones periapicales, aunque uno de los hombres presenta, también, osteomielitis localizada en los lacrimales; una mujer muestra osteomielitis localizada en el frontal y en los parietales, asociada con periostitis.

Aparato masticador y sistema dentario. Se analizaron 54 individuos, entre los cuales 45 eran adultos y nueve subadultos, con un total de 636 piezas permanentes y 157 decíduas.

Se verifica una gran pérdida de piezas dentarias durante la vida del individuo, con un promedio de 13.5 piezas por persona adulta; este promedio sube hasta las 16.6 piezas por mujer, siendo que para los hombres es de 10.7 piezas. Solamente dos mujeres (entre 19 y 25 años) y un hombre (25-30 años), conservan la dentadura completa; esta pérdida se puede explicar por la importante patología dental verificada en esta población, en términos de caries $\mathrm{y}$ de lesiones periapicales.

De un total de 751 piezas examinadas, pertenecientes a 38 adultos y nueve subadultos, se contabilizaron 219 dientes con caries, lo que significa que $29.2 \%$ de las piezas está afectada. El $95 \%$ de los adultos y $55.6 \%$ de los subadultos estaba afectado con caries; sin embargo, las mujeres presentan $42.7 \%$ de sus piezas con caries, en contraste con $26.7 \%$ de los hombres y $13.3 \%$ de los subadultos. Solamente una mujer (20-25 años), un hombre (30-34 años) y un subadulto (12 años), no presentan estas lesiones.

Tal como ya fue observado para otros sitios agroalfareros de San Pedro de Atacama, el desgaste de las piezas dentarias ocurre en Coyo 3 desde edades muy tempranas; a los tres años de edad, los niños ya presentan un grado 3 de desgaste (grados de 1 a 9 de la escala de Molnar 1972); esto es muy superior a lo esperado para poblaciones con dietas blandas, como las basadas en carbohidratos producidos por la agricultura, pero que se verificó también en Quitor 6 y en Solcor 3. Aquí, los hombres presentan un grado promedio de 4.8 de desgaste, y las mujeres, de 4.5. Como ya se explicó para Quitor 6 (Costa 1988), las partículas líticas incluidas en los alimentos a través del proceso de molienda en morteros de piedra, podría ser la explicación para este hecho.

A nivel de patologías alveolares, la más común es la provocada por la perforación de la cámara pulpar causada por caries y/o por desgaste dental intenso, lo que ocasiona la necrosis pulpar, con la formación de lesiones periapicales manifestadas en abscesos y quistes que provocan la excavación de los alveolos y, en muchos casos, la avulsión de las piezas afectadas. En Coyo 3 encontramos que el $94.1 \%$ de las mujeres examinadas $(\mathrm{n}=16 / 10)$, el $95.4 \%$ de los hombres $(n=21 / 22)$ y el $33.3 \%$ de los subadultos $(\mathrm{n}=3 / 9)$ presentan estas lesiones, con promedios de 2.9 para ellas, 3.7 para ellos y 2.3 para los menores, siendo que un hombre y una mujer llegaron a presentar ocho infecciones cada uno. En este aspecto, los hombres son los más afectados, tanto en número de individuos como en incidencia de lesiones por persona.

\section{Cambios degenerativos}

Se verificó que $97.8 \%$ de los individuos adultos examinados presenta osteofitosis en la columna vertebral, a partir de los 20-25 años en las mujeres y de los 30-35 años en los hombres. No hay relación de este rasgo con el sexo, ya que tanto hombres como mujeres son afectados prácticamente por igual. Los grados promedios son bajos en todas las regiones de la columna, aunque las vértebras lumbares presentan los grados más altos: 1.9 (de 1 a 4); las cervicales muestran 1.4 y las lumbares 1.3. Se examinó a 22 hombres y 22 mujeres, encontrando que $76 \%$ de ellas y $70 \%$ de ellos muestran patologías degenerativas 
en las articulaciones, aunque con grados promedios bajos. Las articulaciones más afectadas son las de la nuca (grado promedio 2.0), rodillas (1.0) y codos (0.9) en los individuos masculinos, y nuca, hombros (1.1) y caderas (0.9) para las mujeres. Los resultados indican que las actividades diarias de esta población no suponían un esfuerzo diferenciado entre las diversas articulaciones del cuerpo, así como tampoco entre los dos sexos.

\section{Traumas óseos}

Del total de la población, 25 hombres y 22 mujeres presentaron condiciones de análisis para verificar el grado de exposición a situaciones de violencia, fueran ellas resultado de accidentes de la vida diaria, fueran agresiones en enfrentamientos. No deja de sorprender que sean los individuos femeninos los que presenten mayor cantidad de evidencias de traumas: son 12 las mujeres de ese grupo (54.5\%) y 8 hombres (32\%). El cráneo y la cara son las regiones del cuerpo más afectadas; entre fracturas y cicatrices de golpes (no hay sobrevivencia en el primer tipo mientras que en el otro, sí), aparecen cinco cráneos masculinos y cinco femeninos. En los hombres son más frecuentes las lesiones letales, mientras que las mujeres sobreviven a los traumas. Uno de los varones recibió dos golpes en la cabeza, una herida perforante (¿punta de flecha?) en el parietal y ya tenía una cicatriz de golpe antigua. Las costillas son otro sector muy afectado, con un total de nueve casos, cuatro hombres y cinco mujeres. Aparecen dos mujeres y un hombre con fractura en los brazos. Una de las mujeres presenta una luxación bilateral de la cadera, con alta probabilidad de que sea congénita. No se verificaron traumas en los cuerpos infantiles.

\section{Discusión}

El análisis de la cerámica de Coyo 3 permitió determinar dos asociaciones alfareras bien definidas, las que, junto con el comportamiento diferencial de las otras categorías artefactuales, con las características antropofísicas y con la distribución espacial de los enterratorios, llevó a detectar la existencia de dos grupos de gente inhumados en este cementerio.

El Grupo A, definido básicamente como portadores de cerámica correspondiente a la asociación a, estaría representado por las tumbas $6,8,9,12,15,16,17$, $21,22,23,26,27$ y 48 . Dado que estas tumbas se distribuyen en el sector sur del cementerio, por sectorización, también podemos asimilar a este grupo los enterratorios sin cerámica correspondientes a las tumbas 18, 19, 20, 22 y 47.6 La divergencia del Grupo A en relación al Grupo B es más bien cuantitativa que cualitativa, ya que los ajuares del primer grupo son bastante más modestos que los del segundo. En cuanto a la deformación craneana intencional, en el Grupo A se registran solamente cráneos deformados: $85.7 \%$ con deformación tabular erecta, $7.1 \%$ con deformación circular erecta y $7.1 \%$ con circular oblicua.

Al Grupo B, por presentar contextos cerámicos de asociación b, se asigna las tumbas 1, 2, 5, 7, 28, $29,40,41,44,45$ y 49 y, por sectorización (sector norte del cementerio), también las tumbas 30,31 , $32,33,34,35,36,37,46,50$ y 51 que carecen de alfarería; las tumbas 2, 3, 4, 5 y 49 aun teniendo alfarerías foráneas o de filiación indefinida, pueden incorporarse a este grupo por ubicarse en el sector norte del cementerio. ${ }^{7}$ Los ajuares de estas tumbas son más abundantes que los del Grupo A. Al parecer, la diferencia más significativa entre los componentes artefactuales de uno y otro grupo se relaciona con el complejo psicotrópico y los metales. Sólo en las tumbas asignadas al Grupo B se registran tabletas para alucinógenos; por su parte, objetos de oro y de cobre son exclusivos del Grupo B, aunque también se registra plata; en el Grupo A sólo hay objetos de plata. Por otro lado, en el Grupo B se da $84.2 \%$ de deformación tabular erecta y $15.7 \%$ de cráneos no deformados, no registrándose deformación circular en ninguna de sus variedades. Los cuerpos de camélidos se encuentran en tumbas de este grupo.

El universo de tumbas del cementerio Coyo 3 muestra cierta homogeneidad en sus características, aunque también algunos rasgos diferenciales. La proporción entre hombres y mujeres en el Grupo A es exactamente la misma, en tanto que en el Grupo B la proporción de hombres es $10 \%$ más alta que la de las mujeres. La cantidad de niños en

6 Sólo la tumba 6, que presenta cerámica Tipo 1 (asociación b), se ubica en el sector del Grupo A, pero hemos señalado en el Anexo la divergencia de estas piezas con otras de su grupo en cuanto a la forma de los labios, por lo que podría tratarse de un contexto foráneo.

7 Hay tumbas sin alfarería a las que, por ubicarse en la franja fronteriza entre ambos sectores, hemos preferido no asignar a ninguno de los grupos. 
el Grupo A es de $11.1 \%$, en cambio, en el Grupo B es de $25.7 \%$. La mayoría de las diferencias que se observan, como se dijo, son de tipo cuantitativo y, en menor proporción, de tipo cualitativo. Esto hace ver que se trata de dos grupos diferentes, pero que están compartiendo un sustrato cultural común.

En general, se puede decir que no hay diferencias significativas en el patrón de distribución de la cerámica entre los grupos A y B y, en ambos grupos, la cantidad asociada a las mujeres es menor, lo que ya pone en evidencia un privilegio de los varones. Por otro lado, la cantidad de hombres solos sin cerámica es menor que el de aquéllos enterrados con cerámica; en cambio, entre las mujeres, la cantidad es la misma tanto para las que tienen cerámica como para las que no la tienen. Esto, atendiendo a porcentajes significativos, da una mayor relación de varones en tumbas individuales y con cerámica. Entre los varones, a mayor edad, mayor la cantidad de cerámica en su contexto.

Hay también tendencia a favorecer a los varones en lo que se refiere a la posesión de equipos alucinógenos y en cuanto a ofrendas de camélidos enteros; por otro lado, el único objeto de oro encontrado en el sitio se hallaba con un hombre. Pocos individuos sobresalen notoriamente en lo referente a sus ofrendas o a la cantidad de energía empleada en los rituales funerarios, aunque las tumbas de hombres con tabletas para alucinógenos se encuentran entre las más profundas.

En cuanto al nivel de foraneidad, el indicador más decisivo lo constituye la alfarería. Se puede apreciar que en tres casos la alfarería foránea se encuentra en contextos con cerámica local y en cuatro, aparece como único contexto alfarero. Estos últimos casos son: una individual de hombre; una, con mujer y feto y otra más, con un individuo de sexo indeterminado más un feto. En las tumbas portadoras de cerámica foránea tenemos tres con hombres solos, una con mujer y niño, una con mujer y feto, una con individuo indeterminado y feto, una con sólo un niño y una con dos niños. Lo anterior indica que la presencia de cerámica foránea no privilegia ni sexo ni edad en Coyo 3.

Los puntos de interacción exógena en el sitio se pueden detectar por seis vasijas de procedencia definida, lo que señala relaciones directas o indirectas de la gente de Coyo 3 con poblaciones del sur de Bolivia y del noroeste de Argentina. La vasija 13668 (tumba 39) se puede asignar al estilo Huruquilla (sur de Bolivia); la 13376 (tumba 23) podría corresponder a un estilo regional de la alfarería Aguada, del cual hemos visto piezas similares en forma y/o decoración en el Museo Arqueológico de Cachi (Noroeste Argentino); los ejemplares 13226 (tumba 3) y 13345 (tumba 4) son kero que pueden clasificarse como Tiwanaku Decadente; por último, la pieza 14143 (tumba 48) podría provenir de la región de Yavi.

Algunas de las tumbas con alfarería foránea se pueden asignar por sectorización a algunos de los grupos ya mencionados: las tumbas 16, 23 y 48 al Grupo A; las tumbas 3 y 4 al Grupo B; las tumbas 39 y 42 caen en la franja fronteriza. En general, no se observa ningún patrón definido en estos enterratorios en cuanto a sexo y/o edad; sin embargo, es interesante observar que las tumbas asignables al Grupo A son mixtas en su ajuar alfarero (local y foráneo); en cambio, el resto es exclusivamente foráneo. Por otro lado, las únicas dos tumbas con kero tiwanaku son asignables al Grupo B. Asimismo, no podemos dejar de llamar la atención sobre el caso de la mujer de la tumba 23 que porta una vasija Aguada (13376) y presenta un patrón de entierro diferente al del resto de los individuos inhumados en este cementerio (decúbito lateral).

En cuanto al complejo del alucinógeno, representado por siete tabletas, cinco tubos, seis espátulas/ cucharas, se asocia a nueve individuos masculinos y a uno al que no fue posible determinarle el sexo, lo que significa que $41 \%$ de los hombres de Coyo 3 poseía algún tipo de estos implementos. En este rubro, los conjuntos más completos (tableta, tubo y espátula/cuchara) son los de las tumbas 31, 35 y 44. El individuo de la tumba 46 presentaba dos tabletas, mientras que los de las tumbas 37 y 41, sólo tenían tabletas. En la tumba 50 se encontró una tableta y una espátula. Los demás enterratorios presentaban solamente espátula/cuchara. Así, solamente siete hombres tenían tableta $(31.8 \%)$. Los individuos portadores de tabletas presentan edades entre 30 y 50 años, con un modo que se ubica alrededor de los 40 años; excepción hace a esto, un caso cuya edad se diagnostica en 21-23 años. Es interesante señalar que la edad de los que portan elementos psicotrópicos sin tableta es mayor que la de aquellos que la tienen en su equipo (45-50 años).

En relación a los instrumentos de trabajo, las hachas y/o martillos aparecen en nueve entierros, 
ninguno de mujer; hay un solo gancho de atalaje con un hombre y siete torteras con mujeres. Si consideramos las puntas líticas dentro de este rubro, consignamos 12 en contextos masculinos, una con un niño y otra con una mujer. Preformas de collares hay dos casos asociados a varones $y$, uno a mujer.

Las fechas radiocarbónicas de que disponemos para el sitio están respaldando una contemporaneidad de los dos grupos analizados: 960 DC para la tumba 5 del Grupo A y 910 y 920 DC, respectivamente, para las tumbas 15 y $17 \mathrm{del}$ Grupo B.

Oakland (1992), utilizando los textiles de Coyo Oriente, logra distinguir dos estilos textiles distintos, lo que señalaría también la existencia de dos grupos en este otro cementerio. El análisis de los textiles, la cestería, la cerámica y los artefactos de madera en otros cementerios demuestra, dice la autora, que uno de los grupos estaba más ampliamente distribuido en San Pedro de Atacama y que continuó con algunas modificaciones de estilo en el Período Intermedio Tardío. El otro grupo está asociado más con el oasis de Coyo y tiene textiles y artefactos únicos e iconografía tiwanaku. Estos resultados le sugieren que un grupo representa el estilo y grupo étnico local (Grupo A) y el otro (Grupo B), es de un grupo étnico diferente asociado estrechamente con Tiwanaku. Con una fecha radiocarbónica para el Grupo A de 677 DC y cinco fechas para el Grupo B cuyo rango va entre 639 y $910 \mathrm{DC}$, la autora respalda la contemporaneidad de ambos grupos.

Nosotros, frente a este suge-rente planteamiento, contrastamos los listados, de tumbas del Grupo A y del Grupo B publicados por Oakland, con datos de otros rubros, tales como cerámica y complejo psicotrópico del mismo sitio (Llagostera 1993). Una primera observación nos muestra la condición cualitativa general de las tumbas. Para el Grupo A se observó un promedio de 2.0 individuos por tumba y, para el Grupo B, de 1.5 individuos; es decir, el Grupo B denota un mayor individualismo en lo que respecta al patrón funerario. El Grupo A presentó un promedio de 0.3 vasijas; en cambio, el promedio del Grupo B es de 1.3 vasijas; hay tres tumbas con más de tres vasijas y dos con más de 10. Este último dato concuerda con el hecho de que el Grupo B presenta ajuares más variados y numerosos en diversas categorías de objetos.
Por su parte, la relación de tabletas para alucinógenos por grupo en Coyo Oriente dio $14 \%$ de tumbas portadoras para el Grupo A y 55\% para el Grupo B. La supremacía de este rubro para el Grupo B es evidente y así también, la presencia de estilos clásicos tiwanakotas en la iconografía de las tabletas aunque siempre, entre otros variados estilos. La morfología cerámica no manifestó diferencias significativas entre los contextos de uno y de otro grupo; llama, sí, la atención, el hecho de que no se registra ninguna vasija que tenga características tiwanakotas clásicas. Con todo lo expuesto se confirma la validez de los dos grupos reportados por Oakland para Coyo Oriente ya que, sumándose a la información entregada por los estilos textiles, están otros aspectos que refuerzan la segregación planteada. Al mismo tiempo queda de manifiesto un estatus mayor para el Grupo B.

Ya que se habla de diferentes "grupos étnicos", quisimos buscar a través de un rasgo antropofísico, como la deformación craneana, un indicador que apoye tal afirmación. Lo más significativo que se observó fue la diferencia en ambos grupos entre cráneos no deformados y deformados, donde resulta que mientras en el Grupo A hay una fuerte tendencia a deformarse el cráneo, en el Grupo B cerca de la mitad de la gente no se deforma.

En suma, todos los antecedentes avalan la real existencia de dos grupos para Coyo Oriente; sin embargo, la proposición de sincronismo nos planteaba reservas por sustentarse en una sola fecha para el Grupo A; fecha que, además de coincidir con las más tempranas del Grupo B, se debilita totalmente si consideramos el rango más/menos. Esto nos inducía a mantener cautela y no descartar la alternativa de diacronismo de los dos grupos de Coyo Oriente. Con la repetición del hallazgo de dos grupos en Coyo 3, separados por una distancia de 300 años de los grupos postulados para Coyo Oriente, nos parece que la cuestión queda definitivamente resuelta en favor de la hipótesis de sincronía. Esto significa aceptar el hecho de que en el Período Medio de San Pedro de Atacama hubo presencia de dos grupos conviviendo estrechamente.

La estrecha convivencia de dos grupos compartiendo separadamente un espacio es reconocido por la antropología en la categoría de parcialidades definidas como mitades, las que, a su vez, son una expresión de una organización sociopolítica 
dual. La etnohistoria, por su parte, nos ilustra sobre la existencia de organizaciones duales en la región andina y en nuestro territorio en tiempos precolombinos.

Hidalgo (1971) señala que del testimonio de los cronistas se colige que los habitantes de los valles del Norte Chico poseían gobiernos duales, los que corresponderían a una organización en mitades. Cada una de ellas reconocía un territorio y un cacique o curaca; el límite entre ambas se situaba en una línea hipotética que cortaba los valles de norte a sur, quedando al este una parcialidad de la sierra y otra de la costa, al oeste, siendo probable que la población estuviese repartida en mitades. Si esta última posibilidad fuese cierta, agrega Hidalgo, la estructura de las organizaciones duales del Norte Chico tendría elementos comparables, desde el punto de vista de la territorialidad, con las sociedades prehispánicas que ha investigado Murra en Perú. $\mathrm{Al}$ respecto señala semejanzas en un aspecto con los lupaqa y en otro con los chupaychu.

Desde el punto de vista de la territorialidad a la que se refiere Hidalgo, el caso de Coyo 3 se aproximaría más a una situación semejante a la de los lupaqa. Murra (1964: 426) comenta al respecto que, al igual que en otros lugares andinos, aquí prevalecía el sistema de mitades o parcialidades duales. No sólo había un señor hanansaya para los siete pueblos lupaqa, que en este caso era Cari, sino que también había un señor urinsaya, Cusi. Por otro lado, seis de los siete pueblos que forman parte del señorío lupaqa también estaban divididos en dos parcialidades hanansaya y urinsaya, cada una con su propio señor.

Mariscotti (1978: 82-83) comenta que la existencia de un sistema dual panperuano y preincaico es un hecho que ha quedado claramente comprobado a través de trabajos que han demostrado que éste hallaba expresión en las concepciones míticas de las distintas tribus, y se ponía particularmente de manifiesto en ciertas ocasiones ceremoniales. Sociológica y geográficamente, su vigencia se exterioriza a través de la división de las aldeas en dos mitades, que se identifican con puntos cardinales opuestos o con los conceptos de arriba y abajo. Tomando el estudio que Barthel (1959) efectuó en la localidad atacameña de Socaire, Mariscotti dice que no parece caber duda de que una concepción dualista del mundo había subyacido a la división de las montañas sagradas de Socaire en dos grupos identificados con los rumbos norte y sur pues, a la peculiar forma de invocarlas, se suman diversos elementos ceremoniales tendientes a hacer resaltar el polarismo de los sexos. Aunque carezcamos -agrega ella- de datos concretos, consideramos probable que la división de los montes haya reproducido originariamente a la de la aldea en mitades.

En sus referencias a los lupaqa, Murra (1964) dice que el acceso que los señores de cada una de las parcialidades tenían a los privilegios y a los recursos eran cualitativamente comparables. Sin embargo, el señor hanansaya tenía un estatus más alto, así como acceso a mayores recursos que los que tenía su par. Es evidente que en Coyo 3 hay un desbalance en el acceso a recursos entre el Grupo A y el Grupo B. Del análisis precedente queda en claro que el segundo grupo muestra un nivel de estatus más jerarquizado que el primero; aparte de manifestar una pujanza generalizada, se observa una mayor concentración de elementos de poder: las seis tabletas del sitio están en este grupo, también los cuatro camélidos enteros, la presencia de un hacha y una mayor cantidad de martillos ${ }^{8}$ y el único disco de oro. Desde esta perspectiva parece ser que el personaje de la tumba 35 fue el "señor" de mayor rango, entre todos los que sobresalen por su estatus en el cementerio Coyo 3.

Agradecimientos Este artículo se origina del Proyecto FONDECYT 1188-89.

8 Dado el carácter deleznable del material con que fueron elaborados estos instrumentos, pensamos que se trata de artefactos simbólicos de estatus, de igual categoría que las hachas. 


\section{ANEXO \\ Tipología alfarera de Coyo 3}

Tipo 1. Vasijas en forma de segmentos tangenciales de esfera (platos) (Figura 4). Se registran 14 ejemplares distribuidos en las tumbas $6,8,9,12$, $15,16,17,22,23,47$ y 48 , con un promedio de 1.3 vasijas por tumba. En cinco casos el Tipo $1 \mathrm{se}$ presenta solo y en otros cinco aparece asociado a los tipos 5 (dos veces), 7, 11 y 16 .

\begin{tabular}{|c|c|}
\hline $\mathbf{N}^{\mathbf{0}}$ Registro & Tumba \\
\hline 13238 & 8 \\
13241 & 9 \\
13273 & 6 \\
13274 & 6 \\
13278 & 15 \\
13288 & 17 \\
13290 & 17 \\
13293 & 16 \\
13314 & 12 \\
13364 & 23 \\
13374 & 22 \\
13375 & 22 \\
13758 & 48 \\
13771 & 48 \\
\hline
\end{tabular}

Sus diámetros se distribuyen entre 130 y $255 \mathrm{~mm}$, observándose tres concentraciones, lo que nos permite formar tres grupos de acuerdo al tamaño: a) piezas de tamaño grande, entre 215 y $255 \mathrm{~mm}$ de diámetro (cinco ejemplares); b) piezas de tamaño mediano, entre 165 y $200 \mathrm{~mm}$ (cinco ejemplares); c) piezas de tamaño pequeño, entre 130 y $145 \mathrm{~mm}$ (cuatro ejemplares).

Estos platos presentan un índice de relación alto/ ancho que va de 0.28 a 0.43 con un promedio de 0.35 y con modo de $0.32,0.34$ y 0.36 , coincidiendo con los promedios de los grupos de tamaño: 0.31 para el grupo a, 0.34 para el grupo b y 0.36 para el grupo c.

El espesor de la pared va de 5 a $7 \mathrm{~mm}$, con un promedio de 5.2 para el grupo a, 5.4 para el grupo b y 6.2 para el grupo c. El índice entre espesor de volumen y pared va desde 0.40 hasta 3.33 , con promedio de 0.60 para el grupo a, 1.63 para el grupo b y, 2.57 para el grupo c, lo que indica que hay una tendencia de relación proporcional entre el volumen y el espesor de la pared del recipiente.
En el perfil parietal se dan todas las situaciones enumeradas para la alfarería de Coyo 3 , excepto la 8 y la 9 , encontrándose una frecuencia de $42.8 \%$ para el perfil 2, de $14.2 \%$ tanto para el perfil 1 como para el perfil 5 y de $7.1 \%$ para cada uno de los perfiles restantes. Esto quiere decir que hay una tendencia hacia labios engrosados, con base igual o más gruesa que la pared. En el grupo a se hacen presentes los perfiles 1, 2, 6 y 7; en el grupo b, los perfiles 2, 4 y 5 , y, en el grupo c, los perfiles $1,2,3$ y 5 .

De las seis formas de labios, los tipos 1, 2, 3 y 4 están representados en el grupo de los platos. La mayor representatividad está dada por el tipo 1, con $57.1 \%$; el tipo 4 con $21.4 \%$, el 3 con $14.2 \%$ $\mathrm{y}$, el 2 con $7.1 \%$. El grupo a presenta los tipos $1 \mathrm{y}$ 3; el grupo b, los tipos 1, 3 y 4, y el grupo c, los tipos 1, 2 y 4 . Hay que hacer notar que las únicas dos piezas (13273 y 13274) con labios de tipo 3 pertenecen a la misma tumba (Tumba 6).

En general, las vasijas del Tipo 1 presentan una manufactura poco cuidadosa. El tratamiento de superficie interior es pulido estriado, en algunos casos con notorios rayones; hay un caso pulido con surcos (13273) y otro alisado (13374). Al exterior, la mayoría presenta sólo un burdo alisado; dos ejemplares muestran un pulido estriado en el tercio superior (13758 y 13771); otros, un ligero pulido con surcos. Dos de los ejemplares de platos, uno mediano (13238) y otro grande (13375), están quebrados y presentan orificios de remiendo. Esta intervención y el hecho de que sean los más abiertos (índices alto/ancho de 0.30 y 0.28 , respectivamente) hace pensar que estas piezas son foráneas. Una de ellas, la 13375, presenta un grabado postcocción en su interior, representando un camélido (Figura 7). El análisis petrográfico de las piezas 13278 y 13364 presentan circón en su pasta, elemento que se hace presente en la pieza 14143 (Tipo 15) procedente de la región de Yavi, por lo cual las piezas precedentes podrían también ser foráneas. El colorido de las superficies es bastante irregular, con manchas claras y oscuras. Al mismo tiempo que se observa una tendencia a tonos más oscuros al interior de las piezas, queda en evidencia un patrón variable entre la alternativa del color exterior y el del interior (el ejemplar 13314 es el único que tiene color claro al interior). Las combinaciones cromáticas que ocurren son las siguientes: 


\begin{tabular}{|l|l|c|}
\hline \multicolumn{1}{|c|}{ Exterior } & \multicolumn{1}{c|}{ Interior } & $\mathbf{N}^{\mathbf{0}}$ ejemplares \\
\hline negro & negro & 1 \\
negro & gris muy oscuro & 1 \\
gris muy oscuro & negro & 3 \\
gris muy oscuro & café grisáceo muy oscuro & 1 \\
gris rojizo oscuro & negro & 2 \\
café rojizo & gris muy oscuro & 3 \\
café rojizo & café oscuro & 1 \\
café rojizo & café rojizo & 1 \\
rojo & negro & 1 \\
\hline
\end{tabular}

Filiación: Local (las piezas 13238 y 13375 podrían ser foráneas, como así también las 13273, 13274, 13278 y 13364).

Tipo 2. Vasijas en forma de media esfera (pucos) (Figura 4). Se registran siete ejemplares distribuidos en las tumbas 1, 7, 29, 40 y 45, con una representación de 1.1 vasija por tumba. En tres casos el Tipo 2 se presenta solo y, en dos, asociado al tipo 3 .

\begin{tabular}{|c|c|}
\hline $\mathbf{N}^{\mathbf{0}}$ Registro & Tumba \\
\hline 13212 & 1 \\
13272 & 7 \\
13359 & 29 \\
13676 & 40 \\
13739 & 45 \\
\hline
\end{tabular}

Su índice de relación alto/ancho es mayor que el del Tipo 1 y va de 0.47 a 0.60 , con la mayor frecuencia entre 0.53 y 0.57 . Los diámetros son menores que para el Tipo 1 y se enmarcan entre 108 y $132 \mathrm{~mm}$, hallándose la mayor frecuencia entre 115 y $120 \mathrm{~mm}$.

En general, se puede decir que son piezas de paredes gruesas; si bien se encuentran espesores de $7 \mathrm{~mm}$, el promedio es de 5, 6 y el modo es de $6 \mathrm{~mm}$. Lo anterior se refuerza con la relación entre espesor de pared y volumen, que tiene un promedio de 0.61 .

El perfil parietal es variable dentro de las situaciones 2, 3 y 4; en consecuencia, el borde puede ser más grueso, igual o más delgado que la pared y la base puede ser igual o más gruesa que ésta. En este tipo de vasijas se encuentran representadas las formas de labios 1, 2 y 6 .

Por el tratamiento de superficie se pueden distinguir tres grupos: a) cara exterior alisada con pulido burdo en la mitad superior y pulido burdo en la cara interior (13212 y 13676). La pieza 13212 es la burda del grupo a (a lo que se suma el mayor tamaño y grosor de pared); b) cara exterior pulida burda y cara interior alisada (13272) (esta variedad se mantiene como hipotética ya que el único ejemplar está muy erosionado); c) cara exterior e interior alisadas (13359 y 13739). La pieza 13739 es la más burda del Tipo 2.

En las variantes recién señaladas, las formas de labios se distribuyen de la siguiente manera: 1 en el grupo a, 2 en el grupo b y 2 y 6 en el grupo c.

Los colores presentes son negro, gris muy oscuro y café rojizo; aunque en general el color se distribuye irregularmente, la pieza 13272 es la más irregular en este sentido, al combinar el negro con áreas café rojizas. La combinación de colores al exterior e interior de las vasijas se presenta de la siguiente manera:

\begin{tabular}{|l|l|c|}
\hline \multicolumn{1}{|c|}{ Exterior } & \multicolumn{1}{|c|}{ Interior } & $\mathbf{N}^{\mathbf{0}}$ ejemplares \\
\hline negro & negro & 1 \\
negro & gris muy oscuro & 1 \\
gris muy oscuro & negro & 1 \\
café rojizo & negro & 1 \\
café rojizo & café rojizo & 1 \\
\hline
\end{tabular}

Filiación: Local.

Tipo 3. Vasijas de forma globular restringidas, con el borde levemente evertido (Figura 4). Se registran seis ejemplares, distribuidos en las tumbas 1,7 , 28,41 y 44, con una representación de 1.3 vasijas por tumba. En un caso el Tipo 3 se encuentra solo, y en tres casos asociado con los tipos 2 y 6 (dos veces).

\begin{tabular}{|c|c|}
\hline $\mathbf{N}^{\mathbf{0}}$ Registro & Tumba \\
\hline 13211 & 1 \\
13233 & 7 \\
13728 & 44 \\
13730 & 44 \\
13831 & 41 \\
14149 & 28 \\
\hline
\end{tabular}

La relación alto/ancho en este tipo alfarero va de 1.38 a 1.68 , con la mayor concentración entre 1.47 y 1.57. En cuanto a volúmenes se pueden distinguir dos grupos: a) entre 1050 y $1205 \mathrm{ml}$, que corresponde a piezas grandes $(13728,13730$ y 14149); b) entre 
590 y $665 \mathrm{ml}$, correspondiente a piezas medianas (13211, 13233 y 13831). La relación ancho/boca va desde 1.38 a 1.68 .

Las paredes de este grupo son bastante delgadas en sus valores netos y muchos más, si son consideradas en relación al tamaño de las vasijas. Los espesores van de 4 a $5 \mathrm{~mm}$, coincidiendo el promedio y la media en $4 \mathrm{~mm}$. El índice volumen/pared oscila entre 1.47 y 2.62. El grupo a da un índice promedio de 2.51 y el del grupo b de 1.53 . El perfil parietal está representado por la situación 2, vale decir, borde y base engrosados. Sólo en un caso (13211) se ajusta al perfil 1.

La ubicación del ancho máximo se sitúa aproximadamente en la parte media del cuerpo, con índice de ubicación entre 2.06 y 2.21. Las formas de labio presentes en este grupo son las 1 y 3 , con la segunda como mayor frecuencia. En el grupo a aparece exclusivamente la forma 3.

Las terminaciones de superficie son pulidas, excepto en la pieza 13211 que es pulida burda. La tendencia cromática predominante es el negro o gris muy oscuro; sólo un caso se enmarcaría como café grisáceo muy oscuro.

Dentro de la homogeneidad de este tipo, la pieza 13211 es la que presenta mayor disparidad dentro del conjunto; exhibe el más alto índice volumen/ pared en el grupo $b$, tonalidad café en lugar de negra o gris y el tratamiento de superficie más burdo. Filiación: Local (dislocándose la pieza 13211).

Tipo 4. Formas troncocónicas invertidas y evertidas, de base convexa (Figura 4). Hay tres ejemplares que aparecen en las tumbas 2, 5 y 49, con una representación de una vasija por tumba. La de la tumba 49 no tendría asociación directa con el cuerpo. El Tipo 4 en tres casos aparece sin otra asociación alfarera.

\begin{tabular}{|c|c|}
\hline $\mathbf{N}^{\mathbf{0}}$ Registro & Tumba \\
\hline 13221 & 2 \\
13281 & 5 \\
13782 & 49 \\
\hline
\end{tabular}

La relación alto/ancho presenta valores de 0.65 , 0.70 y 0.72 , manifestándose como formas más anchas que altas. El espesor de las paredes es de 4 y $5 \mathrm{~mm}$, lo que resulta en espesores relativos variables, con índice de volumen/pared de 0.77 , 1.93 y 3.00. El perfil parietal se define como de situación 2: borde y base engrosados. Los labios corresponden a la forma 1 .

El ejemplar de menor tamaño (13221) presenta una base menos convexa y, en consecuencia, más evidente; por su parte, el ejemplar mayor presenta como peculiaridad el hecho de ser el menos evertido.

La técnica de superficie difiere en las tres vasijas del grupo: 13221 es alisado al exterior y al interior; 13281 es alisado burdo al exterior y pulido con surcos al interior y 13782 es pulido estriado al exterior y al interior. El color también difiere en los tres ejemplares, aunque coincide el color exterior con el del interior: negro (13782), gris muy oscuro (13221) y café oscuro (13281). Filiación: Local.

Tipo 5. Formas troncocónicas invertidas con asa cinta vertical en posición media del cuerpo; bases planas y de menor diámetro que la boca (Figura 4). Hay cinco ejemplares distribuidos en las tumbas $16,17,21,26$ y 27 , con frecuencia de una vasija por tumba. En tres casos el Tipo 5 se presenta solo y en dos casos acompañado por los tipos 1 y 7 .

\begin{tabular}{|c|c|}
\hline $\mathbf{N}^{\mathbf{0}}$ Registro & Tumba \\
\hline 13287 & 17 \\
13292 & 16 \\
13336 & 21 \\
13349 & 27 \\
13351 & 26 \\
\hline
\end{tabular}

El índice de relación alto/ancho va de 1.01 a 1.17, con una dispersión heterogénea. El espesor de las paredes varía de 4 a $8 \mathrm{~mm}$, con un promedio de 5 , $4 \mathrm{~mm}$ y relación volumen/pared entre 1.14 y 2.15 , con un caso (13336) que se desfasa hasta 3.86, por su gran tamaño. El perfil parietal se encuadra dentro de las situaciones 3 y 6 , las que, coincidiendo en sus bases gruesas (en dos ejemplares llegan a $13 \mathrm{~mm}$ ), difieren en un borde de igual espesor que la pared, o menor que ésta.

Los labios se definen como de forma 1, excepto en el caso de 13292, donde se observa una arista más afilada, que podría insertarse en la forma 2.

En general, estas vasijas son de factura descuidada, asimétricas y burdas, excepto la 13336, que es 
simétrica y de terminación afinada. Cuatro ejemplares muestran pulido burdo en la cara externa, con estrías o surcos y, el quinto, pulido fino. El tratamiento de la cara interna varía en cada caso: alisado con pulido grosero en el borde (13351 y 13287), alisado con pulido burdo en el borde (13349), alisado a espátula (13292) y alisado con pulido fino en el borde (13336).

Llama la atención el gran tamaño de la vasija 13336 (164 $\mathrm{mm}$ de alto por $160 \mathrm{~mm}$ de ancho). Por otro lado, mientras se observa un predominio de paredes convexas, la pieza 13292 las presenta rectas, siendo además bastante asimétrica. Por otro lado, la vasija 13349 difiere de las demás por presentar el borde evertido.

El color se distribuye irregularmente en las superficies dejando porciones expuestas de color natural de la cerámica. Predominan el negro y el gris muy oscuro; hay un caso en que al exterior es rojo (13292). Las combinaciones entre exterior e interior son las siguientes:

\begin{tabular}{|l|l|c|}
\hline \multicolumn{1}{|c|}{ Exterior } & \multicolumn{1}{|c|}{ Interior } & $\mathbf{N}^{\mathbf{0}}$ ejemplares \\
\hline negro & negro & 3 \\
gris muy oscuro & negro & 1 \\
rojo & gris muy oscuro & 1 \\
\hline
\end{tabular}

La vasija 13336 presenta características significativas que la alejan bastante del resto del conjunto dentro del Tipo 5. Por su parte, la vasija 13349 tiene aplicación de pigmento rojo postcocción. Filiación: Por su heterogeneidad podrían tener diferentes procedencias.

Tipo 6. Vasijas de forma troncocónica invertida compuesta, con inflexión en la mitad inferior de la pieza. La mitad superior se encuentra ornamentada con diseños grabados (Figura 4). Este tipo está representado por cuatro ejemplares presentes en las tumbas 41 y 44, con una representación de 1.3 vasijas por tumba. El Tipo 6 aparece en un caso solo y, en otro, acompañado del Tipo 3.

\begin{tabular}{|c|c|}
\hline $\mathbf{N}^{\mathbf{0}}$ Registro & Tumba \\
\hline 13686 & 41 \\
13727 & 44 \\
13729 & 44 \\
\hline
\end{tabular}

El índice de relación alto/ancho en estas piezas se centra entre 0.51 y 0.55 , llamando la atención la coincidencia en la última cifra de dos piezas de la misma tumba. Las paredes se definirían como de espesor medio, con $4 \mathrm{~mm}$, a excepción de la pieza 13686 (la de mayor tamaño) en la que su pared llega a los $6 \mathrm{~mm}$. La relación volumen/pared va entre 1.57 y 3.14 , correspondiendo el último índice a la pieza 13686, lo que muestra que para su volumen la pared es delgada. Los cuatro ejemplares presentan base engrosada y borde del mismo espesor que la pared, es decir, se encuadran en la situación 3 de perfil parietal; hay dos piezas (13686 y 13729) que tienen base muy espesa (11 y $10 \mathrm{~mm}$ ). Hay una coincidencia en la presencia de labio de tipo 1.

Las vasijas de este grupo son las que presentan la factura más cuidadosa entre todas las de Coyo 3, en cuanto al tratamiento de superficie; son finamente pulidas, tanto al exterior como al interior. En estas piezas predomina el negro al exterior y al interior, excepto en una (13729) que es de color rojo claro en ambas caras. La pieza 13391 sobresale por la irregular coloración de áreas negras y café rojizo.

La decoración del 13686 consiste en una secuencia de rombos reticulados (Figura 8a); la de las vasijas 13727 (Figura 8b) y 13729 (Figura 8c), vale decir, los dos ejemplares de la tumba 44 , por cuerpos de camélidos estilizados ("juego de cola" sensu Le Paige). El ejemplar 13729 presenta una línea negra continua en todo el labio. Filiación: Local.

Tipo 7. Forma hemisférica con dos asas en forma de mamelones situadas a $1 \mathrm{~cm}$ del borde (Figura 4). Se registra sólo un ejemplar correspondiente a la tumba 16 y asociado con los tipos 1 y 5 .

\begin{tabular}{|c|c|}
\hline $\mathbf{N}^{\circ}$ Registro & Tumba \\
\hline 13.294 & 16 \\
\hline
\end{tabular}

Su relación alto/ancho es de 0.43 , lo que lo ubica en el límite entre el Tipo 1 y el Tipo 2. Las paredes son relativamente gruesas con valor de 7 $\mathrm{mm}$, aunque su relación volumen/pared de 1.36 lo distancia del Tipo 2. La base levemente engrosada y el borde de espesor igual al de la pared, ubican esta pieza dentro del perfil 3. El labio es de tipo X $\mathrm{y}$ el tratamiento de superficie es alisada al exterior y pulido al interior. En ambas caras presenta color rojo y lleva una burda decoración de manchas negras irregulares en el labio. Filiación: Foránea. 
Tipo 8. Forma hemisférica con asas macizas labioadheridas (Figura 4). Hay un solo ejemplar que proviene de la tumba 3 , asociado al Tipo 14 .

\begin{tabular}{|c|c|}
\hline $\mathbf{N}^{\mathbf{0}}$ Registro & Tumba \\
\hline 13224 & 3 \\
\hline
\end{tabular}

Su relación alto/ancho es 0.43 , lo que lo sitúa también en el límite entre el Tipo 1 y el Tipo 2. A la inversa del tipo anterior, sus paredes son más bien delgadas ( $4 \mathrm{~mm}$ ), lo que se confirma en un índice volumen/pared de 1.51, distanciándose de las vasijas del Tipo 2 . Su perfil parietal corresponde a la situación 2: borde y base engrosados. La forma de labio es de tipo 5. La superficie se encuentra espatulada al exterior y pulida burda al interior. La definición cromática al exterior y al interior es café oscuro. Filiación: Foránea (?)

Tipo 9. Forma troncocónica invertida, con base constreñida, paredes convexas en los $4 / 5$ superiores y rectas en el quinto inferior, decoración pintada (Figuras 4 y 9a). Existe un solo ejemplar, encontrado en la tumba 39 y asociado al Tipo 12.

\begin{tabular}{|c|c|}
\hline $\mathbf{N}^{\mathbf{0}}$ Registro & Tumba \\
\hline 13668 & 39 \\
\hline
\end{tabular}

La relación alto/ancho es de 0.84 . La relación entre boca y base es de 2.94 y su volumen es de $355 \mathrm{ml}$. La pared presenta un espesor de $4 \mathrm{~mm}$ y la relación volumen/pared es de 0.88 . El perfil parietal es de tipo 7, es decir, pared y borde de igual espesor y base más delgada que éstos. Labio de forma 3. La superficie exterior es bruñida llana y la interior, pulida. En la vasija se observan sectores irregulares de coloración básica rojo claro al exterior y amarillo rojizo al interior, y un cromo intencional gris ceniciento en ambas caras, con decoración geométrica en negro. Filiación: Huruquilla (Chuquisaca).

Tipo 10. Forma troncocónica invertida con paredes levemente cóncava-convexas y con decoración pintada (Figuras 5 y 9b). Existe un solo ejemplar procedente de la tumba 42 , y sin otra asociación alfarera.

\begin{tabular}{|c|c|}
\hline $\mathbf{N}^{\mathbf{0}}$ Registro & Tumba \\
\hline 13700 & 42 \\
\hline
\end{tabular}

Su relación alto/ancho es de 0.96 y su volumen, de $655 \mathrm{ml}$. El grosor de la pared es de $4 \mathrm{~mm}$ y la relación volumen/pared, de 1.63. El perfil parietal es de tipo 3 y el labio de forma 4 , vale decir, con arista interna. La superficie externa es bruñida llana y la interna, pulida. El color básico es café rojizo claro al exterior y al interior, con decoración tricolor: negro, rojo y blanco al exterior y franja roja, en el borde interior. Filiación: Foránea.

Tipo 11. Forma casi hemisférica, de boca restringida y base cóncava. Aplicaciones en pastillaje opuestas, en el borde; una de ellas representa la cabeza de un quirquincho y la otra, la cola del animal. La decoración se complementa con diseños pintados (Figuras 5 y 10a). Sólo un ejemplar en la tumba 23 asociado al Tipo 1.

\begin{tabular}{|c|c|}
\hline $\mathbf{N}^{\mathbf{0}}$ Registro & Tumba \\
\hline 13376 & 23 \\
\hline
\end{tabular}

Indice de relación alto/ancho de 0.46 y volumen de $275 \mathrm{ml}$. El ancho máximo se ubica en un valor de 1.23 , con relación a la altura y la relación ancho/ boca es de 1.01. Pared de $5 \mathrm{~mm}$ de espesor, con relación volumen/pared de 0.53 . Perfil parietal tipo 8: pared más gruesa que el borde y la base. El labio es de forma 7. La técnica de superficie para las caras externa e interna es el pulido. El color básico de la cara externa es amarillo rojizo y el de la cara interna, rojo amarillento; decoración en negro con franjas rojas. Filiación: Aguada (?)

Tipo 12. Vasija compuesta con cuerpo de paredes convexas que se inflexionan en su tercio inferior para modificarse en levemente convexas hasta la base, que es recta. El cuello es un troncocono invertido muy moderado y levemente evertido. Presenta un asa vertical acintada que une el tercio superior del cuerpo con el borde.

Lleva decoración grabada (Figuras 5 y 10b). Un solo ejemplar en la tumba 39 asociado al Tipo 9.

\begin{tabular}{|c|c|}
\hline $\mathbf{N}^{\mathbf{0}}$ Registro & Tumba \\
\hline 13667 & 39 \\
\hline
\end{tabular}

Relación alto/ancho de 1.03, con un volumen de $725 \mathrm{ml}$. El ancho máximo se ubica en 2.70 y la relación ancho/boca en 1.26. La pared entra en la categoría de las muy delgadas, con un espesor 
de $2 \mathrm{~mm}$ y la relación volumen/pared, de 3.62. El perfil parietal se circunscribe en la situación 2 y el labio al tipo 1. Tanto la pared externa como la interna son bruñidas. Sus superficies son negras y en el cuello presenta una decoración de figuras geométricas grabadas, rellenas con un fino achurado vertical, en el asa se marcaron tres gruesas rayas longitudinales. Tiene aplicación de pigmento rojo postcocción y una perforación para "matar" la pieza. Filiación: Foránea.

Tipo 13. Forma hemisférica con dos asas mamelonares a medio cuerpo (Figura 5). Un solo ejemplar asociado a la tumba 7 , acompañado de los tipos 2 y 3 .

\begin{tabular}{|c|c|}
\hline $\mathbf{N}^{\mathbf{0}}$ Registro & Tumba \\
\hline 13232 & 7 \\
\hline
\end{tabular}

Relación alto/ancho de 0.68, índice que asigna una altura proporcional mayor que cualquier tipo hemisférico anterior. El índice para la ubicación del ancho máximo da 1.5 y la relación ancho/boca da un valor de 1.0, lo que indica que la porción superior de la vasija es cilíndrica. El volumen es de $710 \mathrm{ml}$ y el grosor de la pared es de $5 \mathrm{~mm}$, lo que da un índice de 1.42. El perfil parietal es de tipo 2 y el labio de forma 3. La superficie de la vasija es pulida tanto en su cara exterior como en la interior. La cara exterior es gris muy oscuro y la interior es café rojizo. Filiación: Local (?).

Tipo 14. Forma troncocónica con ensanchamiento anular en el tercio superior, evertida en la boca y con base plana (vasos kero); uno de los ejemplares (13345) presenta su mitad inferior de forma cilíndrica. Decoración pintada en negro (Figura 5). Un ejemplar fue hallado en la tumba 3 y otro en la tumba 4. En un caso aparece solo y en otro asociado al Tipo 8.

\begin{tabular}{|c|c|}
\hline $\mathbf{N}^{\mathbf{0}}$ Registro & Tumba \\
\hline 13226 & 3 \\
13345 & 4 \\
\hline
\end{tabular}

El índice de relación alto/ancho es de 1.33 en uno (13226) y de 0.95, en el otro (13345); esta última medida está dada por una mayor eversión de la boca. El volumen es de 465 y de $850 \mathrm{ml}$ respectivamente, con valores de relación volumen/pared de 1.16 y 2.12, siendo las paredes de $4 \mathrm{~mm}$ en ambos casos.
El perfil es de tipo 3 en el primero y tipo 5 en el segundo. En cuanto a los labios, son de forma 1 y 2. Las superficies son pulidas en ambos casos, al exterior y al interior de las piezas. El color básico exterior e interior tiende al rojo (rojo, rojo oscuro, rojo suave y café rojizo) y la decoración, aunque diferente en los motivos, coinciden en ser pintura negra en ambos casos (Figura 11a).

Por la diferenciación de características se puede considerar cada ejemplar como representante de variantes distintas dentro del país. Filiación: Tiwanakoide.

Tipo 15. Globular antropomorfo. Forma compuesta por un cuerpo esférico y un cuello levemente cónico invertido; este último presenta paredes suavemente convexas. Base evidente, con una convexidad muy suave. El cuello presenta rasgos faciales por un solo lado, con ojos, nariz, boca-mentón y orejas modeladas al pastillaje (Figuras 5 y 11b). Un solo ejemplar en la tumba 48 asociado al Tipo 1.

\begin{tabular}{|c|c|}
\hline $\mathbf{N}^{\mathbf{0}}$ Registro & Tumba \\
\hline 14143 & 48 \\
\hline
\end{tabular}

Indice de relación alto/ancho 1.27 y volumen 2685 $\mathrm{ml}$. El ancho máximo de la pieza se ubica justo a la mitad del cuerpo. El ancho máximo del cuello coincide con la abertura de la boca y corresponde a 1.60 del ancho máximo del cuerpo. La pared tiene un espesor promedio de $5 \mathrm{~mm}$ y la relación volumen/ pared es de 5.37. El perfil parietal corresponde a la situación 3 y el labio se adscribe al tipo 1.

El exterior de la vasija es pulido y lo mismo al interior del cuello. La decoración consiste en modelado al pastillaje de rasgos faciales en el cuello de la vasija, ojos fusiformes horizontales muy próximos al borde, con incisión lineal; nariz pronunciada, subtriangular, tableada vertical; boca obtenida por una escarificación elipsoidal horizontal; mentón amamelonado de desarrollo horizontal; orejas arriñonadas con el borde superior contactando el labio de la pieza, plataforma auricular cóncava que se abre oblicuamente mirando hacia el frente y arriba.

El cuerpo mantiene el color base de la vasija (café rojizo) pero en todo el cuello se aplicó pintura roja débil. Además, se alcanza a distinguir pintura negra que fue aplicada en el canto de la nariz, en la incisión 
de los ojos y en forma de una línea que saliendo de las comisuras de la boca se dirigen oblicuamente en dirección a las orejas, sin llegar a ellas. Estas últimas fueron líneas aplicadas sobre una franja crema que corre en la misma dirección.

A través del análisis petrográfico se detectó circón en la pasta. Filiación: Foránea (¿región Yavi?).

Tipo 16. Vasija piriforme vertical de pequeño tamaño, de base aplanada y factura descuidada. Su boca, representada por un mero orificio de $7 \mathrm{~mm}$ de diámetro, se ubica en la porción restringida de la pieza (Figura 6). Se registra un ejemplar en la tumba 9 asociado al Tipo 1.

\begin{tabular}{|c|c|}
\hline $\mathbf{N}^{\mathbf{0}}$ Registro & Tumba \\
\hline 13248 & 9 \\
\hline
\end{tabular}

Relación alto/ancho de 0.93 , con el volumen más reducido de la alfarería de Coyo 3, sólo $20 \mathrm{ml}$. Las paredes son gruesas $(6 \mathrm{~mm})$ para un tamaño tan reducido. El perfil parietal es de tipo 8 y labio atípico, de arista filosa interior, determinada por la factura de la boca. La erosión superficial sufrida por la pieza no permite determinar la técnica de superficie ni el color, así como tampoco saber si tuvo o no decoración. Filiación: Desconocida.

Tipo 17. Forma globular pequeña con la parte superior levemente achatada, teniendo por boca un orificio de $8 \mathrm{~mm}$ de diámetro, con débil reborde. Próximo a la boca tiene una pequeña perforación oblicua que comunica con la cavidad interior. Sólo un ejemplar, asociado a la tumba 14, sin otro acompañamiento alfarero (Figura 6).

\begin{tabular}{|c|c|}
\hline $\mathbf{N}^{\mathbf{0}}$ Registro & Tumba \\
\hline 13369 & 14 \\
\hline
\end{tabular}

Su relación alto/ancho es de 0.74 , con un volumen de $30 \mathrm{ml}$. Al igual que en el caso anterior, las paredes de $7 \mathrm{~mm}$ de espesor resultan muy gruesas para una vasija tan pequeña. Perfil parietal tipo 3 , con labio de corte oval que podría asimilarse a la forma 2. Presenta la superficie exterior alisada y la interior, sin trabajo. Pieza muy erosionada. Filiación: Desconocida.

\section{REFERENCIAS CITADAS}

ALDUNATE, C., J. BERENGUER, V. CASTRO, L. CORNEJO, J. L. MARTINEZ y C. SINCLAIRE, 1986. Sobre la cronología del Loa Superior. Chungara 16-17: 333-346.

BARTHEL, T. S., 1959. Ein Fruhlingsfest der Atacameños. Zeitschrift fur Ethnologie 84 (1): 25-45.

BASS, W. M., 1971. Human osteology: A laboratory and field manual of the human skeleton. Special Publication, Missouri Archaeological Society, Columbia.

BERENGUER, J., A. DEZA, A. ROMAN y A. LLAGOSTERA, 1986. La secuencia de Myriam Tarragó para San Pedro de Atacama: Un test por termoluminiscencia. Revista Chilena de Antropología 5: 17-54.

CASTRO, M. y S. QUEVEDO, 1983-84. Proposiciones metodológicas para el estudio de los rasgos no métricos en el cráneo humano. Boletín del Museo Nacional de Historia Natural 40: 173-210.

COSTA, M. A., 1985. Quitor 6: Sector tardío. Memoria de Título, Universidad del Norte, Antofagasta.

- 1988. Reconstitución física y cultural de la población tardía del cementerio Quitor 6 (San Pedro de Atacama). Estudios Atacameños 9: 99-126.
GILBERT, B. M. y T. W. MCKERN, 1973. A method for aging the female os pubis. American Journal of Physical Anthropology 38 (1): $31-38$.

HIDALGO, J., 1971. Algunos datos sobre la organización dual en las sociedades protohistóricas del Norte Chico de Chile. El testimonio de los cronistas. Noticiario Mensual del Museo Nacional de Historia Natural 178: 3-10.

LOVEJOY, C. O., R. S. MEINDI, T. R. PRYZBECK y R. P. MENSFORTH, 1985. Chronological metamorphosis of the auricular surface of the Ilium: A new method for the determination of adult skeletal age at death. American Journal of Physical Anthropology 68 (1): 15-28.

LLAGOSTERA, A., 1993. San Pedro de Atacama: Nodo de complementariedad reticular. Ponencia presentada al Coloquio "Cinco siglos después: La integración surandina". San Pedro de Atacama. En prensa.

MARISCOTTI, A. M., 1978. Pachamama Santa Tierra, contribución al estudio de la religión autóctona en los Andes Centro Meridionales. Indiana 8.

MCKERN, T. W. y S. W. STEWART, 1957. Skeletal agechanges in young males. Head quarters, quartermaster research and development command. Technical Report EP-45, Natick. 
MEINDL, R. y C. O. LOVEJOY, 1985. Ectocranial suture closure: A revised method or the determination of skeletal age at death based on the lateral-anterior sutures. American Journal of Physical Anthropology 68 (1): 57-66.

MEINDL, R., C. O. LOVEJOY y R. P. MENSFORTH, 1985. A revised method of age determination using the Os Pubis, with a review and tests of accuracy of other current methods of pubic symphyseal ring. American Journal of Physical Anthropology 68 (1): 29-46.

MOLNAR, S., 1972. Tooth wear and culture: A survey of tooth functions. Current Anthropology 13 (5): 511-526.

MURRA, J., 1964. Una apreciación etnológica de la Visita. En Visita hecha a la Provincia de Chucuito por Garcí Diez de San Miguel en el año 1567, pp. 421-442. Ediciones de la Casa de la Cultura del Perú, Lima

1975. Las autoridades étnicas tradicionales en el Alto Huallaga. En Formaciones económicas y políticas del mundo andino, pp. 171-192. Instituto de Estudios Peruanos, Lima.
OAKLAND, A., 1992. Textiles and ethnicity: Tiwanaku in San Pedro de Atacama, north Chile. Latin American Antiquity 3 (4): 316-340.

RIVERA, M., 1985a. La problemática Tiwanaku-Wari en el contexto panandino del desarrollo cultural. Diálogo Andino 4: 9-10.

1985b. Alto Ramírez y Tiwanaku, un caso de interpretación simbólica a través de datos arqueológicos en el área de los Valles Occidentales de sur de Perú y norte de Chile. Diálogo Andino 4: 39-58.

UBELAKER, D. H., 1978. Human skeletal remains: Excavation, analysis and interpretation. Aldine Publishing Company, Chicago.

WING, E. y A. BROWN, 1979. Paleonutrition. Academic Press Inc. Studies in Archaeology, Nueva York. 